\title{
Vertical and Horizontal Inequality in Ecuador: The Lack of Sustainability
}

\author{
Ivan Gachet ${ }^{1}$ - Diego F. Grijalva ${ }^{2}$ (D) Paúl A. Ponce ${ }^{3}$ • \\ Damián Rodríguez ${ }^{4}$
}

Accepted: 23 November 2017/Published online: 12 December 2017

(C) UNU-WIDER 2017, corrected publication February 2019

\begin{abstract}
We analyse the evolution of vertical and horizontal inequality in Ecuador in the long-run (1990-2016), as well as during and after the recent commodities boom (20052014). Using data from censuses, living standard measurement surveys, and employment surveys we show that Ecuador has made significant progress in reducing inequality, particularly since 2000. However, inequality has not decreased further since 2011. We argue that a key factor behind the reduction and ensuing stagnation of inequality is the dynamic of oil revenues, particularly regarding its effect on economic growth and on the financing of redistributive policies. Using the decomposition of the Gini coefficient by income source proposed by Lerman and Yitzhaki (Rev Econ Stat 67:151-156,1985) we show that during the last decade there has been a shift away from market sources towards sources of income derived from government expenditures. Following the end of the commodities boom, this process is no longer sustainable. Indeed, we show that the underlying causes that led to the change in the sources of income started long before the end of the boom. The temporary shock following the 2008 financial crisis already affected the structure of Ecuador's public finances and its current account. And, since around 2011, its institutions and labour market indicators have also deteriorated. We conclude that sustainable inequality reductions require improving the current institutions.
\end{abstract}

The original version of this article was revised due to a retrospective Open Access order.

Diego F. Grijalva

dgrijalva@usfq.edu.ec

1 International Independent Consultant, Quito, Ecuador

2 USFQ Business School, School of Economics, and Instituto de Economía, Universidad San Francisco de Quito USFQ, Campus Cumbayá, Quito, Ecuador

3 Secretaría Nacional de Planificación y Desarrollo SENPLADES, Quito, Ecuador

4 Université Paris 1 Panthéon-Sorbonne, Paris, France 
Keywords Ecuador - Horizontal inequality - Vertical inequality · Commodities boom · Sustainability

\section{Introduction}

Ecuador is an unequal country. In 2000, the official income-based Gini coefficient reached 0.565 (SIISE 2016a). Since then, however, and in line with the general trend observed in Latin America, inequality in Ecuador has fallen significantly (Lustig and Lopez-Calva 2010; Lustig et al. 2013; Ponce and Vos 2014; ECLAC 2017). According to SICES (2017), by 2016 its Gini coefficient had fallen to 0.466 . Between-group inequality has also decreased. For instance, the ratio of household per capita income between urban and rural households fell from 2.38 in 2005 to 1.69 in 2016.

Inequality reduction in Ecuador - both vertical (i.e. at the individual level-VI) and horizontal (i.e. between groups-HI) — was particularly large between 2007 and 2011. This period coincides with the first half of the leftist government of President Rafael Correa, which was characterized by its redistributive policies including increases in social spending, public employment, and cash transfers. It also coincides with the peak of oil prices, which meant large windfalls for the Ecuadorian government.

In the context of concurrent oil windfalls and redistributive policies, we ask whether the recent reduction in inequality is sustainable, i.e. if the current level of inequality can be maintained over time. We recognize that further inequality reductions are difficult to achieve (e.g. it is harder to reduce the Gini coefficient from .45 to .40 than it is to reduce it from .55 to .50 ), and thus we do not expect the decline in inequality to continue in the future; we expect inequality to remain at the current level. We would also like to determine the extent to which the observed reduction in inequality is due to the oil revenues or to the redistributive policies. This is a difficult endeavour because of the simultaneity between these two factors. As we discuss below, the main challenge is that it is precisely the abundance of resources that allowed the government to implement these policies.

To shed light into the question of sustainability we look briefly at the theoretical arguments that have been put forward to explain the relationship between commodity booms and inequality, and also look at some empirical evidence. Gylfason and Zoega (2003) develop a theoretical model showing that the abundance of natural resources leads to increased inequality and provide empirical evidence of this effect in a cross-country sample. Their view is consistent with the notion that revenue accruing from oil and minerals is often unequally distributed because elites hold control over the resources and, as a consequence, tend to direct them towards their own benefit. Likewise, Buccellato and Mickiewicz (2009), in a study of the effect of oil and gas on inequality among Russian regions, find that production of these resources increases inequality within the regions. Loayza and Rigolini (2016) find a similar effect of mining in Peru's districts. Contrary to these results, Howie and Atakhanova (2014) find that a resource boom led to a reduction in inequality within Kazakhstan's regions.

Indeed, as pointed out by Ross (2007), the effect can go in either direction. On the one hand, assuming that there are limits to intersectoral labour mobility, inequality should increase following a Dutch Disease argument. The rise in oil exports leads to an appreciation of the real exchange rate, which in turn causes a fall in the competitiveness of sectors other than oil. If the distribution of natural resources is relatively unequal, the 
associated fall in employment in those sectors will cause inequality to rise. On the other hand, Ross (2007) points out that a mineral boom may lead to increased government employment due to the rise in revenue. Since governments tend to compress salaries of their employees, the added public employment would cause inequality to fall. As we point out in this paper, these are clearly not the only mechanisms through which a resource boom can affect inequality. Most importantly, public policies and institutions may have an important effect.

In the case of Ecuador, revenue from the oil boom has been successfully used to finance an expansion of the cash transfer program as well as social security and retirement pensions, both of which have contributed to reduce inequality. As the boom came to an end, however, keeping inequality low has become increasingly costly. As a consequence, we argue that the lower levels of inequality are unlikely to be sustainable in the medium run. Most importantly, the strong economic growth observed since 2008-with the exception of 2009-has morphed into a recession in 2016, and it is expected to continue in 2017 and 2018, followed by weak economic growth up to 2022 (International Monetary Fund 2017). The reduction in inequality stopped after 2011 , and poverty and extreme poverty started to increase following the drop in oil prices in 2014. Weak growth has also meant a deterioration of public finances, and the rise of private and public debt. Because macroeconomic conditions in Ecuador are not expected to change in the near future, the pressure on public finances is likely to increase, turning fiscal consolidation unavoidable. As we explain below, this will drastically limit the ability of the government to continue with its redistributive policies.

Goderis and Malone (2011) provide theoretical and empirical evidence along these lines. They find that although a natural resource boom is associated with a contemporaneous inequality reduction, this effect diminishes gradually as time goes by, until it disappears in the long-run. Our argument is quite similar, but we emphasize different mechanisms. In the short-run, redistributive policies financed with the windfalls from the boom are the key contributors to reducing inequality. In the long-run, deterioration of the fiscal and external sectors, along with labour market distortions and institutional decay are the culprits that lead to the disappearance of this effect.

Throughout the paper, we focus on measures of both vertical inequality (VI) and horizontal inequality (HI). Recent research highlights the relevance of each type of inequality for different outcomes. Stewart $(2000,2008)$ provides evidence that HI plays a central role to explain humanitarian crises and conflict; Donoso et al. (2015) and Stewart (2016) show that VI is relevant to explain criminality. Furthermore, as a middle point between aggregate VI and HI we also analyse within-group VI. This is important because, as argued by Stewart (2008), conflict is more likely to occur when intra-group differences are smallproviding cohesiveness to the group-and inter-group differences are large-highlighting the notion of the "other".

The contributions of the paper are threefold. First, we present a long-run overview of VI and HI in Ecuador, and highlight the progress made during the period 1990-2016, especially during the commodities boom. The analysis of $\mathrm{HI}$ is particularly relevant because, to the best of our knowledge, there are no studies on this regard for Ecuador. Second, we provide empirical evidence of the lack of sustainability of the recent inequality reduction in Ecuador. Our focus here is on the fiscal and external imbalances that emerged after the 2008 financial crisis, as well as the labour market downturn and institutional deterioration that followed. Finally, we provide a political economy explanation for this result.

The paper is structured as follows. In the next section we discuss Ecuador's long-term trends in VI and HI. Section three looks at the dynamics of inequality for the 2005-2016 
period, and analyses the links with the commodities boom and government's policies. Section four provides a brief explanation for these results, and section five concludes.

\section{Long-Term Trends of VI and HI in Ecuador}

Ecuador is a Latin American middle-income country characterized by its geographic, economic, and ethnic diversity. In 2014, its human development index (HDI) was 0.732, corresponding to the high human capital category (World Bank 2017). Ecuador has experienced significant social and economic progress in recent years. Gross national income (GNI) per capita reached 5246 in 2015 (in 2010 PPP \$), compared to 3413 in the year 2000 (World Bank 2017). Inequality has fallen significantly and poverty declined from $64.4 \%$ in 2000 to $22.5 \%$ in 2014 (SIISE 2016a). To understand the significance of the recent progress regarding inequality in Ecuador, in this section we look at VI and HI from a long-term perspective.

\subsection{Vertical Inequality (VI)}

Figure 1 provides VI measures for Ecuador for the 1963-2015 period. We include the Ecuadorian official series of income-based Gini coefficients (SIISE 2016a), as well as Gini coefficients from ECLAC (2017) and World Bank (2017). These are survey-based data and thus provide reliable information; their main limitation is that national data are only available for a few years before 2000. To complement these measures, we also include information from the University of Texas Inequality Project-EHII (2016). ${ }^{1}$ This dataset provides information on the Gini coefficient for the period 1963-2008.

Inequality in Ecuador has varied significantly over time. Based on the EHII data, there was a large fall in inequality during the 1970s. This is relevant for our analysis because the reduction in inequality during this period coincides with the start of oil extraction in Ecuador and the first oil boom. Oil was discovered in 1967 and oil exports began in August, 1972 (Gachet et al. 2011). Between 1971 and 1978 the Ecuadorian economy grew by an average of $8 \%$ per year (Central Bank of Ecuador 2012) and the Gini coefficient—based on EHII data—fell almost six percentage points (see Fig. 1). As is the case with the latest commodities boom, inequality reduction in Ecuador during the $70 \mathrm{~s}$ resembles the experience of other countries in Latin America during the same years (with the exception of Argentina, Chile and Uruguay) (Birdsall et al. 2011; Gasparini and Lustig 2011).

The end of the oil boom at the beginning of the 1980s along with the military conflict with Peru and the onset of the debt crisis led to a decline in Ecuador's economic growth. The economic deceleration was associated with an increase in inequality, which at the end of the decade had reverted back to the level preceding the oil boom (see Fig. 1). In the 1990s, inequality continued to rise amid adjustment policies and market-oriented reforms (Ponce and Vos 2014); and, in 1999 the floods caused by El Niño and the drop of oil prices led to an economic and financial crisis (Gachet et al. 2011). ${ }^{2}$ As a consequence, poverty and inequality increased. The evolution of inequality

\footnotetext{
1 The EHII database provides Gini coefficients for a large sample of countries over a long period of time. EHII uses data from UTIP-UNIDO and a regression of overlapping observations on the original dataset from Deininger and Squire (1996).

2 As pointed out by Martínez (2006), liberalization and weak regulation were key contributors to the crisis.
} 


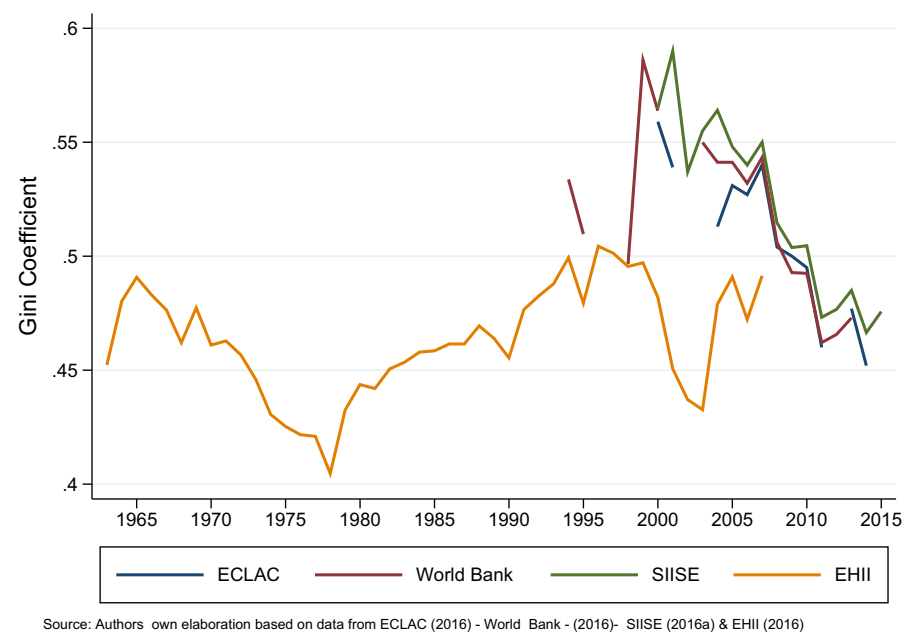

Fig. 1 Ecuador: Inequality over time, 1950-2015. Source: Authors' elaboration based on data from ECLAC (2017), World Bank (2017), SIISE (2016a), and EHII (2016)

during the 1980s and 1990s is also reminiscent of other Latin American countries, although their experiences were more heterogeneous during the latter decade (Gasparini and Lustig 2011).

Figure 1 also shows that starting in 2000 inequality in Ecuador fell significantly. Data from SIISE (2016a), ECLAC (2017), and World Bank (2017) provide a similar picture of strong inequality decline. The EHII data show a decline at the beginning of the 2000s followed by an increase in the middle of the decade. The increase is also shown in the other databases, although it seems less dramatic. ${ }^{3}$ The drop in the 2006-2014 period from a Gini coefficient of .540 to .467 (SIISE 2016a) is remarkable as it implies a decline in the Gini coefficient of almost one percentage point per year. The picture for Latin America is similar, although less pronounced: from 2002 to 2014 the Gini coefficient fell six points (0.55-0.49) (ECLAC 2017). Thus, it seems that the commodities boom helped reduce inequality in the majority of countries in the region, despite their heterogeneous policies.

Several lessons follow from this brief analysis. First, inequality in Ecuador tends to fluctuate significantly over time once we look at a longer historical period. This means that the common notion of persistent inequality in Ecuador should be reconsidered. In particular, persistence does not seem to imply that inequality does not change, but that it tends to revert back to its original high level. Second, inequality in Ecuador tends to follow general regional trends. Third, and most importantly, the recent reduction of inequality is not the first one in Ecuador. A similar fall in inequality occurred during the 1970s, precisely during the first oil boom.

Some authors, looking at survey-based data, argue that the current reduction of inequality in Latin America constitutes a break with the region's history (Birdsall et al. 2011; Cornia 2014; Lustig and Lopez-Calva 2010; ECLAC 2015). As shown above for the case of Ecuador, the fall in inequality — while remarkable — constitutes a break with history only if we do not look back beyond the 1980s. The evidence presented above for Ecuador,

\footnotetext{
3 The reason for this difference may be that EHII, by using UNIDO data, captures only the formal manufacturing sector, which is just a fraction of all economic activity. This is certainly the case in Ecuador where a large fraction of employment is informal and located in non-manufacturing sectors.
} 
as well as additional evidence provided by Gasparini and Lustig (2011) for other Latin American countries, shows that inequality also fell during the 1970 s.

The dynamics of inequality for Ecuador and Latin America during commodity booms seems at odds with the argument presented by Ross (2007) and Ross et al. (2012). According to these authors, revenue accruing from oil and minerals is often unequally distributed within countries because elites hold control over the resources and, as a consequence, tend to direct them towards their own benefit. Thus, contrary to our observations, a resource boom is expected to increase inequality. In light of this argument, Ecuador's recent reduction of inequality is indeed remarkable, and the reduction that took place during the 1970s even more so. Most of that decade the country was governed by a dictatorship and thus governing elites had weak political incentives to distribute oil revenues.

The fact that the abundance of resources does not automatically translate into a reduction in inequality highlights the relevance of government's policies. Social spending (mainly in education), cash transfer programs and other government policies play an important role in reducing inequality (Tsounta and Osueke 2014). But, despite the policies' contribution to reducing inequality, our interpretation of the historical evidence is that they are feasible only when revenues from resource booms become available. In Ecuador, oil windfalls helped sustain strong economic and employment growth, which combined with increased social spending, government employment, and cash transfer programs, led to a large fall in inequality. As shown in Fig. 1, because resource booms are temporary, these reductions in inequality tend to be inherently unsustainable.

\subsection{Horizontal Inequality}

$\mathrm{HI}$ is important in Ecuador because of its social, economic, and political cleavages. The Ecuadorian population is composed of an important fraction of indigenous and AfroEcuadorians, who are concentrated in different parts of the country. There are at least 13 indigenous nationalities distributed across the country (SIISE 2017). According to Alesina et al. (2003), ethnic fractionalization in Ecuador in 1989 was 0.6550, language fractionalization 0.1308 and religious fractionalization $0.1417 .{ }^{4}$ Likewise, according to Fearon (2003) cultural fractionalization in Ecuador was 0.48. These ethnic and cultural scores make Ecuador one of the most fractionalized countries in Latin America.

As argued by Stewart (2000), ethnicity and cultural differences are not the only relevant dimensions to define social cleavages; class and regional location may also matter. In our analysis we make an attempt to balance relevant cleavages with the availability of historical data and representativeness of the survey samples. We include four dimensions: ethnicity, gender, area, and poverty. Before turning to these dimensions, however, we present the databases used.

\subsubsection{Inequality Databases}

We use three different sources of data, as shown in Table 1: national censuses $(1990,2001$, and 2010), living standard measurement surveys (LSMSs) (1995, 1998, 1999, 2006, and

\footnotetext{
${ }^{4}$ Fractionalization reflects the likelihood that two people chosen at random from a given population belong to different groups (Alesina et al. 2003). It is calculated as Frac $=1-\sum_{i=1}^{N} s_{i}^{2}$, where $s_{i}$ represents the share of group $\mathrm{i}(\mathrm{i}=1 \ldots \mathrm{N})$. The measure of fractionalization ranges from 0 to 1 and higher values mean more fractionalization.
} 


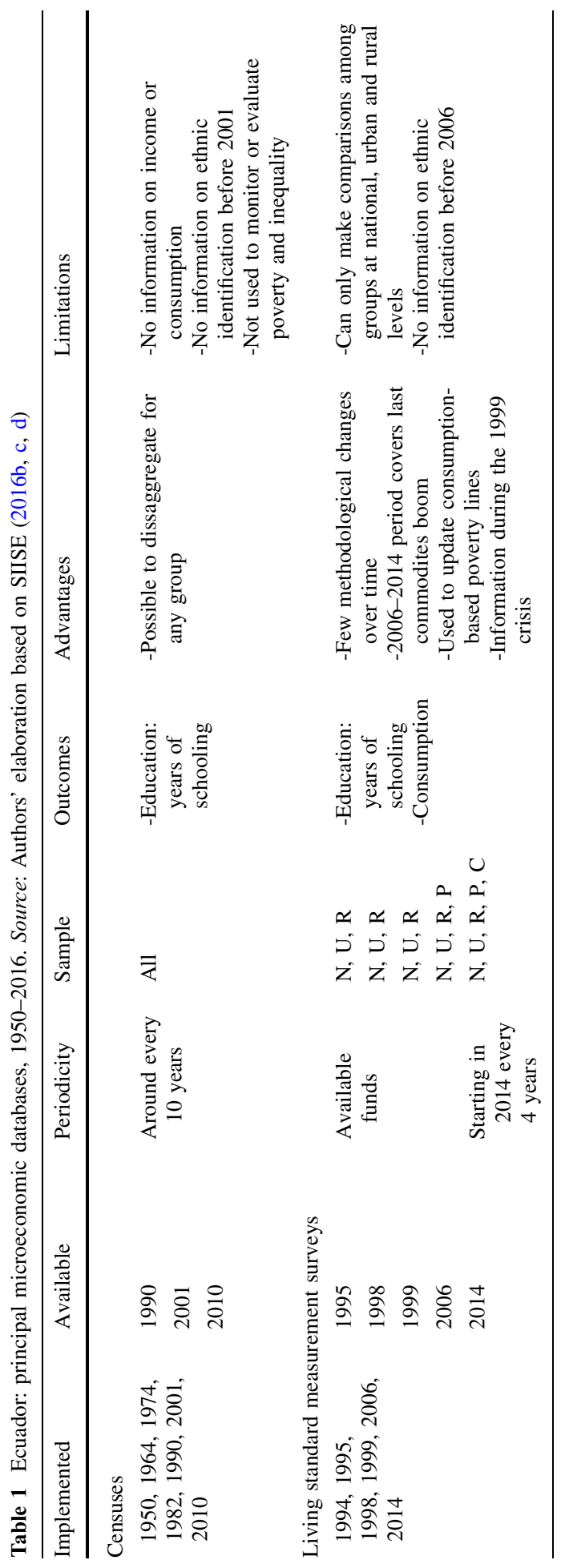




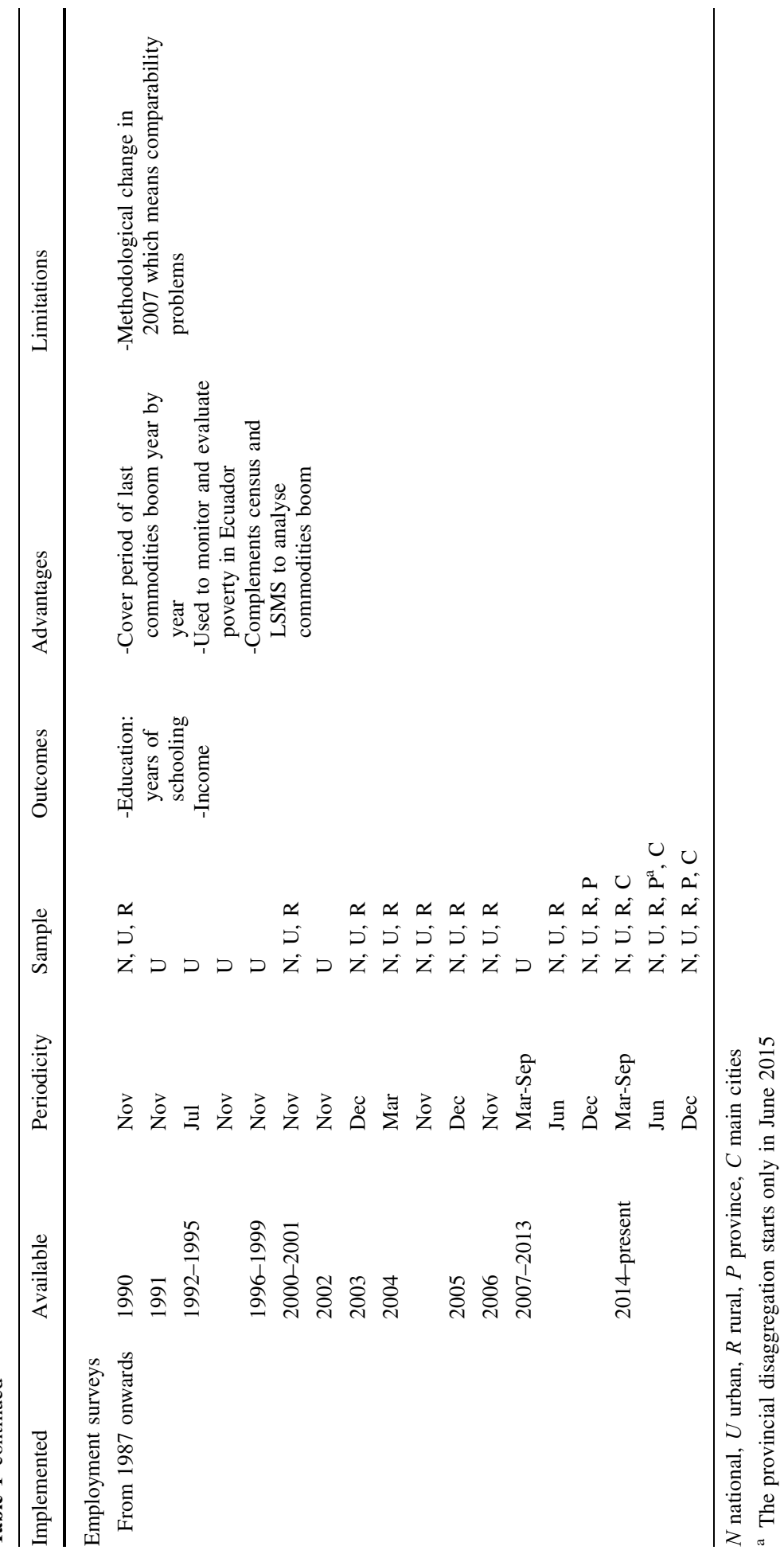


2014) and December Employment Surveys (ESs) (2005-2016). ${ }^{5}$ We discuss each one of these sources in turn. ${ }^{6}$

In Ecuador, seven censuses have been implemented (1950, 1964, 1974, 1982, 1990, 2001, and 2010), but complete data files are only available for the last three. Censuses have the advantage of covering the whole population, but at the cost of not acquiring much information. Most importantly, they do not collect data on either income or consumption, which are the standard variables for measuring poverty and inequality. Thus, to categorize an individual as poor or non-poor in the censuses we use the concept of unsatisfied basic needs (UBN). ${ }^{7}$ To calculate inequality we use years of education. ${ }^{8}$

Because of these limitations, we complement the censuses with two sets of surveys: the LSMSs and the ESs. Ecuador's LSMSs collect information on many dimensions of household well-being such as housing characteristics, consumption, sources of income, some labour market characteristics, educational attainment, and access to public services, among others. These are used to assess household welfare, understand household behaviour, compute consumption poverty lines and evaluate the effect of various government policies on living conditions. They, as well as the censuses, are carried out by Ecuador's National Institute of Statistics and Censuses (INEC). Six LSMSs have been conducted in the country (1994, 1995, 1998, 1999, 2006 and 2014), but complete databases are only available starting with 1995 . Up to 1999 , they are representative only at the national, urban and rural levels. The last two surveys are also representative at the provincial level and for the main cities. Besides having comparable information over time with little methodological changes, an important element of the LSMSs is that it is possible to calculate educational attainment. An additional advantage is that the 1998 and 1999 LSMSs provide information on the effects of the 1999 crisis on VI and HI. Furthermore, the years 19992014 coincide with the period of strong poverty and inequality reduction in Ecuador, with the rise of President Correa's government and also with the peak of the last oil boom. The main limitation of the LSMSs - especially in the older datasets-is that the size of the sample does not allow to separate all ethnic groups or to combine various dimensions simultaneously (e.g. gender and ethnicity).

The ESs are national surveys currently carried out quarterly by Ecuador's National Institute of Statistics and Censuses (INEC). The ESs cover a wide range of economic and socio-demographic information such as labour data, different sources of income, housing, migration, education, and other social indicators, and are used mainly to estimate labour market indicators (unemployment, underemployment, etc.) and poverty rates using income poverty lines. Up to 2002, ESs were conducted in November of each year for urban households only, with the exceptions presented in Table 1. Since 2007, they appear quarterly for urban households, and twice a year (June and December) for urban and rural households, excluding the Galapagos Islands before 2014. The ESs provide information

\footnotetext{
5 In Ecuador, LSMSs are called "Encuesta de Condiciones de Vida (ECV)" and ESs are called "Encuesta Nacional de Empleo, Desempleo y Subempleo Urbano y Rural (ENEMDUR)".

6 The working databases and all the Stata do-files required to replicate this study are available from the authors upon request.

7 According to the UBN approach, a person is classified as poor if he or she belongs to a household that is unable to satisfy its basic needs, including housing, sanitation, education, and employment characteristics (Feres and Mancero 2001). UBN is used in the measurement of poverty and extreme poverty in developing countries, but it is not used to estimate poverty lines. We include the UBN-based poverty categorization to have a long-run perspective on poverty.

${ }^{8}$ Because censuses do not collect data on consumption and income, education is a common variable used for historical comparative analyses on inequality (see Gisselquist 2015).
} 
representative at the national level starting in 2003, but we only use data since 2005 because we found inconsistencies in the 2003 and 2004 datasets.

\subsubsection{Dimensions of Analysis}

We focus on four dimensions of HI that capture the most relevant aspects of betweengroup inequality in Ecuador:

1. Language (non-indigenous vs. indigenous), as a proxy for ethnic cleavages. This is a dichotomous variable defined as 1 if there is a person in the household who speaks an indigenous language and 0 otherwise. We highlight this variable in our analysis of ethnic cleavages because of comparability over time. It is not possible to have long series on ethnicity in either the censuses or the LSMSs using data on ethnic groups because self-reported identification is only available starting with the 2001 census and the 2006 LSMS. $^{9}$

2. Gender (male vs. female).

3. Area (urban vs. rural).

4. Poverty (non-poor vs. poor). This variable is defined in a different way for censuses, LSMSs, and ESs. In the first case, it is based on unsatisfied basic needs (UBN), as explained above. In the LSMSs it is determined by a household consumption-based per capita poverty line, and in the ESs it is determined by a household income-based per capita poverty line. LSMSs and ESs are used to calculate Ecuador's official poverty measures (based on consumption and income, respectively). ESs poverty data is used to monitor this indicator due to its high frequency.

Because we use education as our main variable to measure VI and $\mathrm{HI}$ over the full period, we focus our analysis on people who are 15 years old and above.

Table 2 provides a first glance at VI and HI over time. It presents information based on all the censuses (the three columns on the left) and LSMSs (the five columns on the right) for which we have data. There are four panels showing the population division by language spoken (indigenous vs. non-indigenous), gender, living area, and poverty. In each case, the table shows the shares of the relevant groups in the population and average years of education. In the case of LSMSs, it also shows average consumption.

Let us first consider education. Consistent with the improvement observed worldwide (Barro and Lee 2015), years of education in Ecuador have increased significantly at the aggregate level and also for every subgroup. This progress is concentrated in the last part of the period. Average years of education have increased by around two full years in the last quarter of a century.

As expected, people who do not speak an indigenous language, men, people living in urban areas, and the non-poor have more years of education relative to their respective counterparts, although there is significant heterogeneity. For example, while in 2014 the difference in average years of education between people that do not speak an indigenous language and people that do -and also between people living in urban areas versus those living in rural areas- is around 3.5 years, the difference between men and women is less than .16 years.

Progress among disadvantaged groups (people who speak an indigenous language, women, people living in rural areas, and the poor) has been stronger than among their

\footnotetext{
9 This proxy is not without problems as we discuss below, but it enables a long-run analysis. The distinction between indigenous and non-indigenous speaking households is also used by Caumartin et al. (2008).
} 
Table 2 Ecuador: educational attainment and consumption, censuses and LSMSs, 1990-2014. Source: Authors' estimation based on INEC $(2011,2015)$

\begin{tabular}{|c|c|c|c|c|c|c|c|c|}
\hline & \multicolumn{3}{|l|}{ Censuses } & \multicolumn{5}{|l|}{ LSMSs } \\
\hline & 1990 & 2001 & 2010 & 1995 & 1998 & 1999 & 2006 & 2014 \\
\hline Total population & $59,08,272$ & $81,16,588$ & $99,55,074$ & - & - & - & - & - \\
\hline Sample size & - & - & - & 16,677 & 16,583 & 16,550 & 35,947 & 73,229 \\
\hline $\begin{array}{l}\text { Average years of } \\
\text { education }\end{array}$ & 7.06 & 7.53 & 8.88 & 7.53 & 7.77 & 7.85 & 8.38 & 9.16 \\
\hline Average consumption & - & - & - & 44.64 & 39.73 & 34.33 & 59.90 & 192.87 \\
\hline \multicolumn{9}{|l|}{ Language } \\
\hline \multicolumn{9}{|l|}{ Shares $(\%)$} \\
\hline $\begin{array}{l}\text { No indigenous } \\
\text { language }\end{array}$ & 96.58 & 93.22 & 93.80 & 95.11 & 94.99 & 92.94 & 96.52 & 95.98 \\
\hline $\begin{array}{l}\text { Indigenous } \\
\text { language }\end{array}$ & 3.42 & 6.78 & 6.20 & 4.89 & 5.01 & 7.06 & 3.48 & 4.02 \\
\hline \multicolumn{9}{|c|}{ Average years of education } \\
\hline $\begin{array}{l}\text { No indigenous } \\
\text { language }\end{array}$ & 7.15 & 7.71 & 9.08 & 7.67 & 7.92 & 8.13 & 8.51 & 9.30 \\
\hline $\begin{array}{l}\text { Indigenous } \\
\text { language }\end{array}$ & 3.52 & 5.05 & 6.11 & 4.76 & 4.93 & 4.05 & 4.72 & 5.84 \\
\hline Ratio (RAD) & 2.03 & 1.53 & 1.49 & 1.61 & 1.61 & 2.01 & 1.80 & 1.59 \\
\hline \multicolumn{9}{|l|}{ Average consumption } \\
\hline $\begin{array}{l}\text { No indigenous } \\
\text { language }\end{array}$ & - & - & - & 45.43 & 40.62 & 35.67 & 61.25 & 197.25 \\
\hline $\begin{array}{l}\text { Indigenous } \\
\text { language }\end{array}$ & - & - & - & 29.32 & 22.82 & 16.63 & 22.57 & 88.82 \\
\hline Ratio (RAD) & - & - & - & 1.55 & 1.78 & 2.14 & 2.71 & 2.22 \\
\hline \multicolumn{9}{|l|}{ Gender } \\
\hline \multicolumn{9}{|l|}{ Shares $(\%)$} \\
\hline Male & 48.92 & 48.93 & 48.99 & 48.58 & 48.94 & 48.93 & 48.51 & 48.22 \\
\hline Female & 51.08 & 51.07 & 51.01 & 51.42 & 51.06 & 51.07 & 51.49 & 51.78 \\
\hline \multicolumn{9}{|c|}{ Average years of education } \\
\hline Male & 7.32 & 7.63 & 8.93 & 7.63 & 7.91 & 8.04 & 8.50 & 9.25 \\
\hline Female & 6.81 & 7.44 & 8.85 & 7.44 & 7.63 & 7.67 & 8.27 & 9.09 \\
\hline Ratio (RAD) & 1.07 & 1.03 & 1.01 & 1.02 & 1.04 & 1.05 & 1.03 & 1.02 \\
\hline \multicolumn{9}{|l|}{ Average consumption } \\
\hline Male & - & - & - & - & - & - & - & - \\
\hline Female & - & - & - & - & - & - & - & - \\
\hline Ratio (RAD) & - & - & - & - & - & - & - & - \\
\hline \multicolumn{9}{|l|}{ Area } \\
\hline \multicolumn{9}{|l|}{ Shares $(\%)$} \\
\hline Urban & 69.60 & 74.92 & 75.20 & 62.03 & 59.42 & 61.65 & 65.71 & 68.98 \\
\hline Rural & 30.40 & 25.08 & 24.80 & 37.97 & 40.58 & 38.35 & 34.29 & 31.02 \\
\hline \multicolumn{9}{|c|}{ Average years of education } \\
\hline Urban & 8.01 & 8.18 & 9.47 & 8.99 & 9.30 & 9.34 & 9.64 & 10.20 \\
\hline Rural & 4.88 & 5.58 & 7.12 & 5.15 & 5.51 & 5.43 & 5.96 & 6.86 \\
\hline Ratio (RAD) & 1.64 & 1.47 & 1.33 & 1.74 & 1.69 & 1.72 & 1.62 & 1.49 \\
\hline
\end{tabular}


Table 2 continued

\begin{tabular}{|c|c|c|c|c|c|c|c|c|}
\hline & \multicolumn{3}{|c|}{ Censuses } & \multicolumn{5}{|c|}{ LSMSs } \\
\hline & 1990 & 2001 & 2010 & 1995 & 1998 & 1999 & 2006 & 2014 \\
\hline \multicolumn{9}{|c|}{ Average consumption } \\
\hline Urban & - & - & - & 55.34 & 50.83 & 43.14 & 73.06 & 225.57 \\
\hline Rural & - & - & - & 27.24 & 23.54 & 20.23 & 34.78 & 120.38 \\
\hline Ratio (RAD) & - & - & - & 2.03 & 2.16 & 2.13 & 2.10 & 1.87 \\
\hline \multicolumn{9}{|l|}{ Poverty } \\
\hline \multicolumn{9}{|l|}{ Shares $(\%)$} \\
\hline Non-poor & 23.88 & 31.97 & 43.64 & 65.62 & 60.36 & 53.07 & 67.19 & 78.58 \\
\hline Poor & 76.12 & 68.03 & 56.36 & 34.38 & 39.64 & 46.93 & 32.81 & 21.42 \\
\hline \multicolumn{9}{|c|}{ Average years of education } \\
\hline Non-poor & 10.51 & 10.37 & 11.00 & 8.78 & 9.28 & 9.73 & 9.64 & 9.88 \\
\hline Poor & 5.90 & 6.13 & 7.20 & 5.13 & 5.45 & 5.70 & 5.81 & 6.54 \\
\hline Ratio (RAD) & 1.78 & 1.69 & 1.53 & 1.71 & 1.70 & 1.71 & 1.66 & 1.51 \\
\hline \multicolumn{9}{|c|}{ Average consumption } \\
\hline Non-poor & - & - & - & 59.70 & 56.45 & 52.80 & 79.90 & 228.68 \\
\hline Poor & - & - & - & 15.92 & 14.27 & 13.45 & 18.93 & 61.50 \\
\hline Ratio (RAD) & - & - & - & 3.75 & 3.95 & 3.93 & 4.22 & 3.72 \\
\hline
\end{tabular}

advantaged counterparts. To see this, we introduce the concept of RAD: the ratio of advantaged to disadvantaged, which we use throughout the paper. The RAD compares the average value of a variable (years of education, household per capita consumption, and household per capita income) for the advantaged and disadvantaged group in each dimension of analysis (language, gender, area, and poverty). Because we calculate this ratio for each year of the available databases, it provides a first glance at the dynamics of horizontal inequality in Ecuador. As can be seen, in every panel, the ratio of years of education of the advantaged group to the disadvantaged group (RAD) has fallen. The most significant variation occurs among groups classified by language where the ratio falls from 2.03 to 1.49 based on the censuses. This means that, while in 1990 people who did not speak an indigenous language had slightly more than twice as many years of education than people who did, they had only $49 \%$ more years of education in 2010 . A similar trend can be observed in the other panels.

The LSMSs show that this progress has not been monotonic. As mentioned before, the LSMSs also capture the years 1998 and 1999 in which Ecuador suffered a serious economic and financial crisis. It is notable how between 1998 and 1999 the RAD increases for all four dimensions. The most dramatic change is the one based on language, where the $\mathrm{RAD}$ goes from 1.61 to 2.01. Indeed, between these years there was a decline in average years of education among people who speak an indigenous language and those living in rural areas. This may seem strange, but some possible reasons include migration and also a change in the pattern of education accumulation as people-especially those belonging to disadvantaged groups-were forced to leave school due to the impact of the crisis. An increase in the RAD for education in 1999 thus shows how households facing an economic slowdown may neglect their education.

The effect of the 1999 crisis is even clearer when we analyse household per capita consumption, which is also presented in Table 2. Consumption in 1999 fell for every group in 
every panel relative to $1998 .{ }^{10}$ Moreover, this occurred despite the fact that consumption already fell in 1998 relative to 1995 , consistent with the economic slowdown. While the RAD for poverty, and area did not change much between 1998 and 1999, the rise in the RAD for language (1.78-2.14) should be noted. This change means that consumption among indigenous language speakers fell even more than among speakers of a non-indigenous language. In addition, in the language and poverty panels, the RAD increased between 1999 and 2006, falling only thereafter. This might occur because the post-crisis recovery among disadvantaged groups takes place more slowly, or it might reflect a change in policies after 2006. As mentioned above, the available data do not allow for disentangling the two effects.

Comparing education and consumption, the consumption-based RADs tend to be higher than the corresponding education-based RADs. This is consistent with intuition as there is much more variation in consumption than in education. The most extreme case is shown in the poverty panel. On average, the consumption-based RAD in this panel was 3.91 (i.e. the non-poor consumed on average close to four times what the poor consumed), but the education-based RAD was only 1.66 , which means that the non-poor had only $66 \%$ more years of education than the poor.

Finally, it is important to highlight the large increase in average consumption between 2006 and 2014. In this period, consumption grew by a factor greater than 3.2 (and by a factor close to four for indigenous language speakers), while the CPI increased by around $40 \%{ }^{11}$ This rise in consumption is consistent with the large increase in resources during the oil boom.

Next, we turn to a more detailed analysis of vertical and horizontal inequality among groups. Table 3 shows aggregate Gini coefficients, within-group Gini coefficients, and group-based Gini coefficients (GGini) based on the censuses and the LSMSs. The main difference with Table 2 is that Gini coefficients look at the entire distribution and not only the means, as is the case with the ratios of advantaged to disadvantaged (RADs). As before, we include years of education for the censuses and LSMSs, and also household per capita consumption for the latter. ${ }^{12}$

Looking at the data based on the censuses, the first notable result is the reduction in VI, especially during the period 2001-2010. The education-based Gini coefficient went from 0.38 in 1990 to 0.31 in 2010 . The same trend can be observed in all disaggregated groups, except for the non-poor for whom there was an increase up to 2001 and a decrease thereafter. A similar reduction can be seen based on the LSMSs for the period 1995-2014.

Second, all disadvantaged groups show higher VI than the corresponding advantaged ones. This is important because it is a signal that there exists heterogeneity regarding education among disadvantaged groups and thus, that cohesiveness among them may be weak. Third, in part because of the larger initial inequality among disadvantaged groups, inequality has fallen more among these groups than among the advantaged ones. The greatest difference is between people that speak an indigenous language and those that do not. While the Gini coefficient among the former fell from .37 to .31 over the period 1990 2010, it fell from .61 to .42 for the latter. A similar dynamic can be observed based on the

\footnotetext{
${ }^{10}$ We do not include consumption levels by gender because the LSMSs do not collect individual consumption data. Therefore, a comparison of consumption levels by gender could be made only in terms of female versus male-headed household, which is not informative for our analysis. We thank an anonymous referee for pointing this to us.

11 See INEC (2017a) for historical data on the CPI.

12 We computed similar tables based on the Theil index, with very similar results. They are available from the authors upon request.
} 
Table 3 Ecuador: Gini and group-weighted Gini, censuses and LSMSs, 1990-2014. Source: Authors' estimation based on INEC (2011, 2015)

\begin{tabular}{|c|c|c|c|c|c|c|c|c|}
\hline & \multicolumn{3}{|c|}{ Censuses } & \multicolumn{5}{|l|}{ LSMSs } \\
\hline & 1990 & 2001 & 2010 & 1995 & 1998 & 1999 & 2006 & 2014 \\
\hline Gini coef. education & 0.3777 & 0.3738 & 0.3148 & 0.3443 & 0.3312 & 0.3321 & 0.3171 & 0.2897 \\
\hline Gini coef. consumption & - & - & - & 0.4254 & 0.4451 & 0.4529 & 0.4569 & 0.4071 \\
\hline \multicolumn{9}{|l|}{ Language } \\
\hline \multicolumn{9}{|l|}{ Years of education } \\
\hline No indigenous language & 0.3705 & 0.3634 & 0.3052 & 0.3344 & 0.3230 & 0.3146 & 0.3101 & 0.2825 \\
\hline Indigenous language & 0.6072 & 0.5034 & 0.4228 & 0.5316 & 0.4719 & 0.5347 & 0.4757 & 0.4382 \\
\hline GGini & 0.0171 & 0.0224 & 0.0194 & 0.0180 & 0.0183 & 0.0341 & 0.0152 & 0.0146 \\
\hline \multicolumn{9}{|l|}{ Consumption } \\
\hline No indigenous language & - & - & - & 0.4216 & 0.4416 & 0.4431 & 0.4505 & 0.4021 \\
\hline Indigenous language & - & - & - & 0.4547 & 0.4367 & 0.4815 & 0.4814 & 0.3767 \\
\hline GGini & - & - & - & 0.0168 & 0.0213 & 0.0364 & 0.0217 & 0.0217 \\
\hline \multicolumn{9}{|l|}{ Gender } \\
\hline \multicolumn{9}{|l|}{ Years of education } \\
\hline Male & 0.3620 & 0.3648 & 0.3071 & 0.3342 & 0.3190 & 0.3164 & 0.3063 & 0.2803 \\
\hline Female & 0.3926 & 0.3824 & 0.3220 & 0.3535 & 0.3426 & 0.3469 & 0.3271 & 0.2985 \\
\hline GGini & 0.0178 & 0.0063 & 0.0023 & 0.0061 & 0.0091 & 0.0117 & 0.0070 & 0.0043 \\
\hline \multicolumn{9}{|l|}{ Consumption } \\
\hline Male & - & - & - & - & - & - & - & - \\
\hline Female & - & - & - & - & - & - & - & - \\
\hline GGini & - & - & - & - & - & - & - & - \\
\hline \multicolumn{9}{|l|}{ Area } \\
\hline \multicolumn{9}{|l|}{ Years of education } \\
\hline Urban & 0.3368 & 0.3481 & 0.2933 & 0.2868 & 0.2714 & 0.2703 & 0.2679 & 0.2501 \\
\hline Rural & 0.4362 & 0.4246 & 0.3609 & 0.3825 & 0.3698 & 0.3802 & 0.3658 & 0.3438 \\
\hline GGini & 0.0937 & 0.0648 & 0.0494 & 0.1199 & 0.1178 & 0.1178 & 0.0991 & 0.0780 \\
\hline \multicolumn{9}{|l|}{ Consumption } \\
\hline Urban & - & - & - & 0.4005 & 0.4177 & 0.4246 & 0.4325 & 0.3892 \\
\hline Rural & - & - & - & 0.3677 & 0.3767 & 0.3973 & 0.4007 & 0.3553 \\
\hline GGini & - & - & - & 0.1482 & 0.1656 & 0.1577 & 0.1439 & 0.1166 \\
\hline \multicolumn{9}{|l|}{ Poverty } \\
\hline \multicolumn{9}{|l|}{ Years of education } \\
\hline Non-poor & 0.2497 & 0.2689 & 0.2416 & 0.2972 & 0.2770 & 0.2647 & 0.2742 & 0.2663 \\
\hline Poor & 0.3980 & 0.3988 & 0.3467 & 0.3774 & 0.3592 & 0.3579 & 0.3437 & 0.3252 \\
\hline GGini & 0.1197 & 0.1234 & 0.1056 & 0.1094 & 0.1183 & 0.1279 & 0.1006 & 0.0615 \\
\hline \multicolumn{9}{|l|}{ Consumption } \\
\hline Non-poor & - & - & - & 0.3419 & 0.3484 & 0.3463 & 0.3760 & 0.3539 \\
\hline Poor & - & - & - & 0.1739 & 0.1902 & 0.2021 & 0.1783 & 0.1423 \\
\hline GGini & - & - & - & 0.2213 & 0.2540 & 0.2855 & 0.2244 & 0.1459 \\
\hline
\end{tabular}


LSMSs for the period 1995-2014. The education-based Gini coefficient fell from .34 to .29. There were stronger declines for the disadvantaged groups who, despite these declines, still face consistently higher within-group inequality.

Between-group inequality (HI) has also decreased, but with important variations across dimensions. Language HI increased during the period 1990-2001 and then fell back to around the original level by 2010 . The gender GGini fell by around $87 \%$ during the same period. The largest decline in absolute terms occurred for area, where the GGini fell by 0.04 during this period. Looking at the LSMSs, education-based HI also fell. As before, however, the crisis had a strong effect: HI increased in 1998 and 1999 relative to 1995 in all cases except area, where it fell marginally.

Looking at consumption provides again a more complete picture. VI declined over the 1995-2014 period at the aggregate level and also within groups, except for the non-poor. $\mathrm{HI}$ fell for area and poverty, but it actually increased for language. Interestingly, while education-based Gini coefficients are higher for disadvantaged groups, this is reversed in the cases of area and poverty for the consumption-based Gini coefficients. Most dramatically, the Gini for non-poor has been around twice as high as the one for the poor.

Looking at education and consumption together, it is notable that the reduction in VI and HI did not occur during the whole period, but mainly in the period 2006-2014. Indeed, consumption-based VI was higher in all cases in 2006 than in 1995, and it fell only thereafter. The 1998-1999 crisis also contributed to this pattern. In all the dimensions analysed, the 1999 levels of consumption-based VI and HI were higher than in 1995. Furthermore, as discussed above, the crisis seems to have had a stronger effect on VI among disadvantaged groups. For instance, consider the non-poor versus poor during the 1995-1999 period. While the Gini for the former group increased by less than .005 , it increased by almost .3 for the latter. In percentage terms, these changes correspond to 1 and $16 \%$, respectively. Thus, consumption VI tends to increase during the crisis, and even more for disadvantaged groups. Consistent with this, HI also increased during the crisis: the consumption-based GGini was larger in 1998 and 1999 than in 1995 for all groups.

To conclude this section, we note that the long-run analysis of VI and HI shows that the inequality dynamics are much more complex than just a reduction over time. There has been great progress with regard to education since 1990, although most of it took place after 2000. In general, disadvantaged groups have reduced the educational gap and, particularly in the case of men and women, this gap has been almost completely closed. The crisis of 1999 had a negative effect on the accumulation of education, especially among some disadvantaged groups, who seem to have faced more difficulties in recovering from it. With regard to consumption, most of the reduction in VI and $\mathrm{HI}$ occurred in the last period (2006-2014). Overall, there has been significant progress in reducing inequality. As this progress seems to have concentrated in the latter period, in the next section we turn to the analysis of VI and HI during the commodities boom.

\section{VI and HI During and After the Commodities Boom}

In this section we analyse the dynamics of VI and HI in the period 2005-2016 and its relationship with the commodities boom. We provide evidence that the trend of VI and HI reduction has stopped and argue that there is evidence that inequality may start fluctuating in the near future. 


\subsection{Dynamics of VI and HI}

Table 4 provides December data on years of education and household per capita income for the period 2005-2016 based on the ESs. We focus the analysis on income, as this is the variable on which official poverty lines, and poverty and vertical inequality indicators are constructed in Ecuador.

The first aspect that we note is the very large increase in income over the period 20052015. Income increased by $91 \%$, while the CPI increased by $51 \%$. This implies an increase in real income of over $20 \%$ in 10 years. Likewise, during this period, average years of education increased by more than one year. In 2016, however, we already observe a reversal of this trend as nominal income fell by $4.2 \%$, while CPI rose by $1.1 \%$.

Consider next the evolution of VI and HI. Because we look at consecutive years, changes are more nuanced than in the analysis of the previous section. Despite this fact, we are able to establish various general patterns in line with the evidence presented above.

Let us first take a brief look at education. Consistent with the general trend, average years of education increased almost monotonically over the period for each group, except in the poverty panel. Indeed, in this case, it might seem that not much progress has been made, particularly among the non-poor. However, this is explained in large part by the reduction in poverty. Over the period 2005-2016 the share of poor fell from 37 to $20 \%$. Because the poor tend to be less educated than the non-poor, the mobility of the former into the non-poor pushes down average years of education among the non-poor. Furthermore, if the former poor are on average more educated than the remaining poor-which seems likely - their exit also pushes down average years of education among the poor. Thus, the progress in average years of education shown in the poverty panel provides a lower bound for the actual improvement that took place.

Regarding the education-based ratios of advantaged to disadvantaged (RADs), there is a slow but consistent decline, particularly after 2012. The decline for gender is limited because the educational gap between men and women at the beginning of the period was already very small (.21 years). By 2016, it fell to 0.06 years. This is an important milestone regarding gender equality, as it means that women are acquiring essentially as many years of education as men. ${ }^{13}$

Income has a similar evolution as education, but the data show early signs of a reversal in the last year. There was a strong increase in income for every group up to 2014. In 2015, income continued to increase for every group except those who speak an indigenous language; and in 2016 income fell across the board. Interestingly, in all cases the RADs fell between 2015 and 2016, meaning that so far the negative effect of the economic slowdown has been stronger for the advantaged than for the disadvantaged.

Table 5 provides further information on the 2005-2016 period, including measures of VI and HI. With regard to education, the pattern of VI and HI is also one of consistent decline until 2014. After this, only in the case of gender do we observe a clear continuation of the trend. In the other three panels, there are initial signs of stagnation.

With regard to per capita income, there is also a pattern of decline of VI at the aggregate level and for all groups until 2014. HI also fell, especially in the cases of poverty and area. The most interesting dynamic, however, appears at the end of the sample between 2014 and 2016. Within-group inequality continued to fall among advantaged groups, but it increased among all disadvantaged groups. For instance, while the Gini coefficient for

13 It is important to note that this is only a quantitative assessment and that important qualitative differences may remain regarding e.g. the quality of education, type of education, choice of university major, etc. 


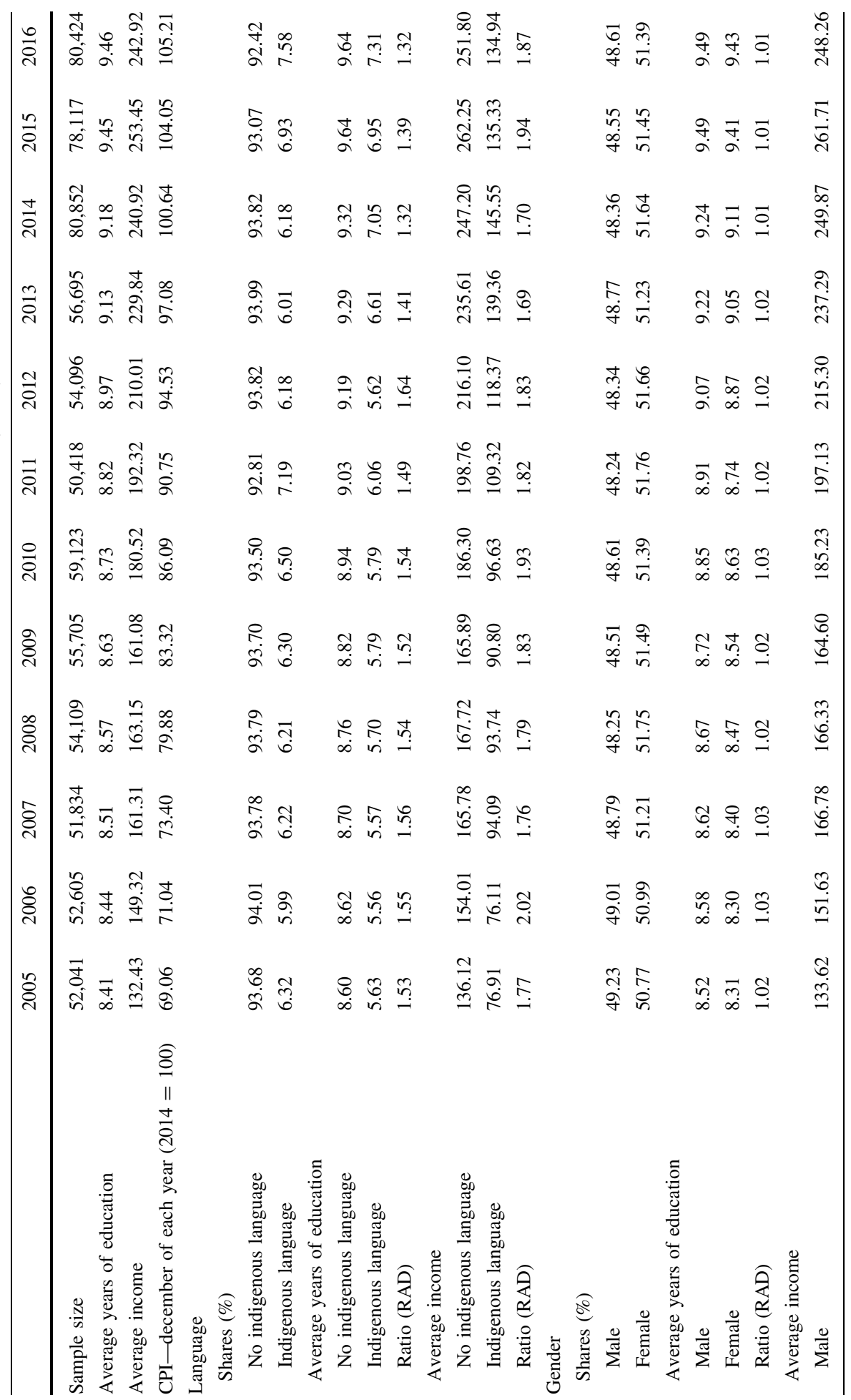




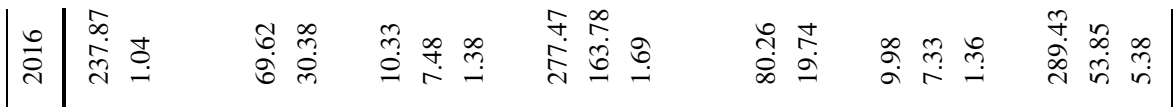

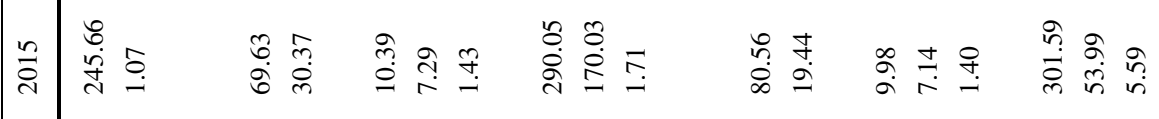

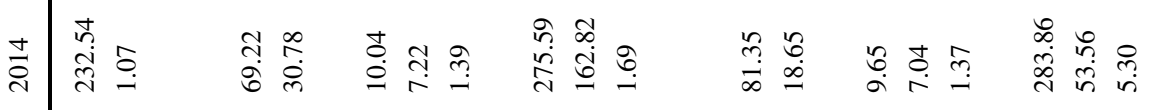

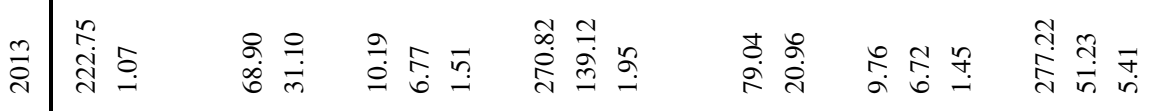

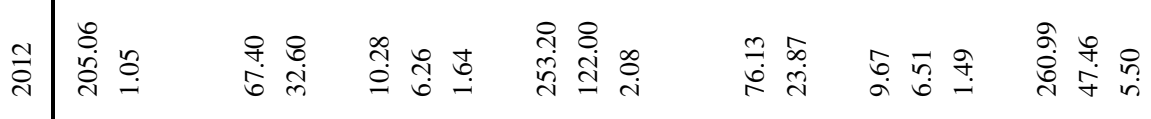

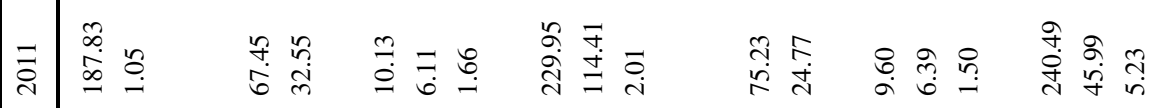

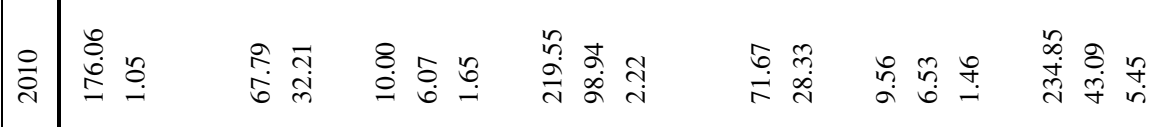

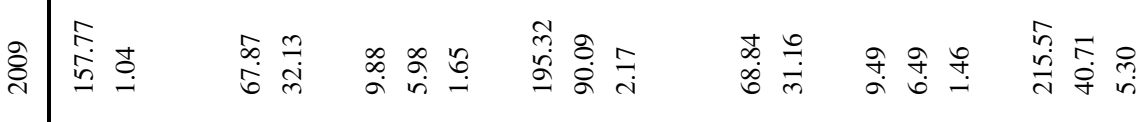

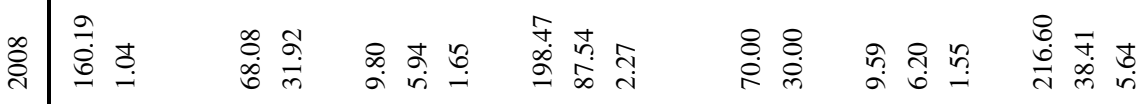

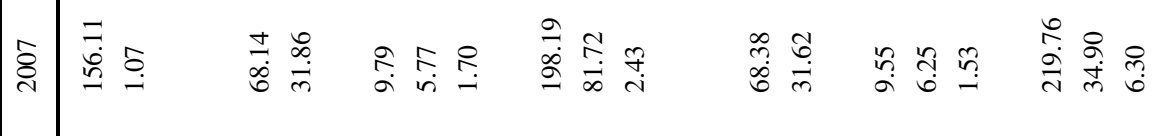

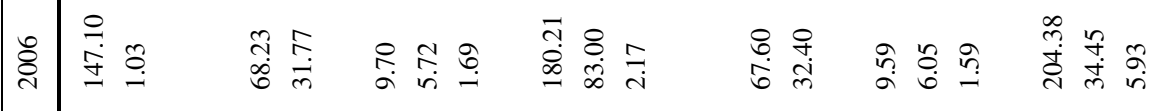

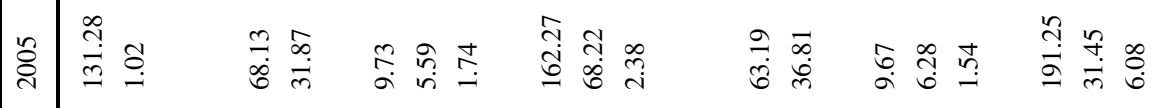

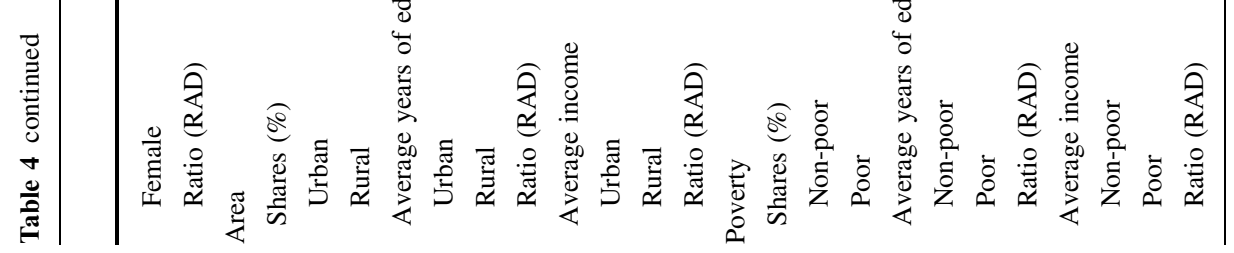




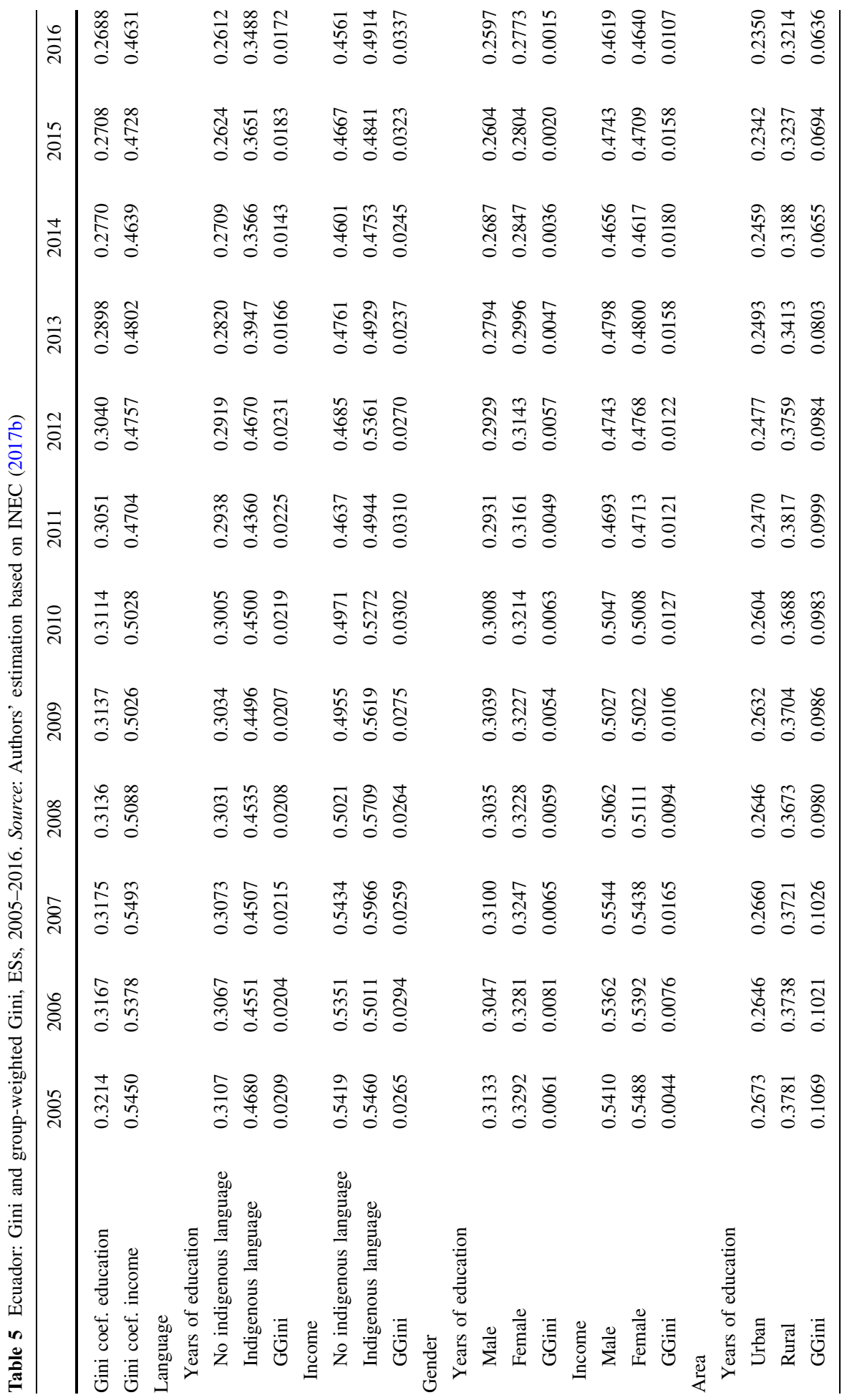




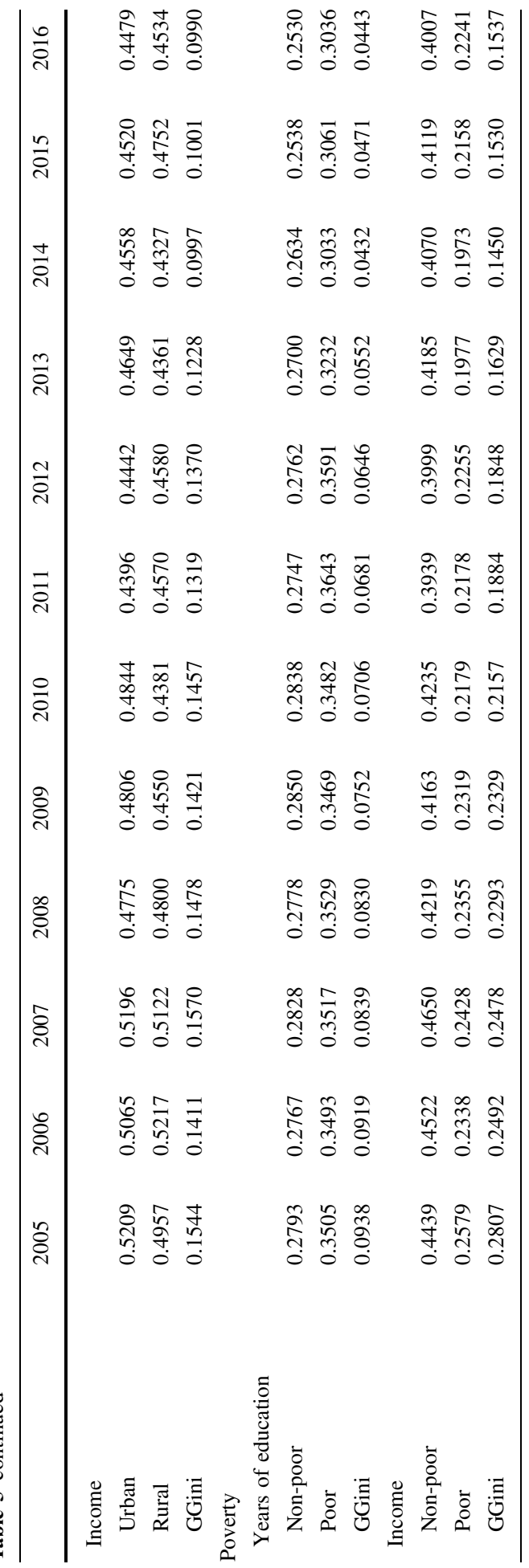


people who do not speak an indigenous language fell from .4601 to .4561 between these years, for people who speak an indigenous language it went from .4753 to .4914 . HI also increased in the cases of language and poverty. For the former, HI increased from .0245 to .0337 , while for the latter it rose from .1450 to .1537 .

We conclude that-for the most part-the cleavages in the four dimensions analysed have been reduced during the last 25 years. All databases show a consistent story along this line, be it in terms of educational attainment, consumption or income. However, consistent with our argument, using the most recent data we showed that there are initial signs of stagnation and, in some cases, of a trend reversal.

\subsection{Effects of the Commodities Boom}

The evidence presented so far shows that Ecuador has reduced its VI and HI in the last decades. In some cases, as in gender and area, existing cleavages have been reduced significantly. However, the data presented in the last section also show the first signs of stagnation, both in terms of VI and HI.

In this section we look at Ecuador's experience with the commodities boom and argue that the recent reduction in inequality, while remarkable, was dependent on the windfalls obtained from the oil boom. To see the context in which the reduction of VI and HI took place, Table 6 summarizes the main macroeconomic, social, and public sector indicators of Ecuador for the period 2005-2016.

With the exception of 2009, 2015 and 2016, GDP growth in Ecuador during the period analysed has been very strong. Indeed, between 2004 and 2014 the average growth rate of GDP was $4.48 \%$. The three years of slow or negative growth were associated with unfavourable external conditions, which can be seen as large drops in the real price of oil and the terms of trade. On the contrary, the years of high growth were associated with increases and/or high levels of these variables. As a consequence, for the period 2005-2016 the correlation between the change in the real price of oil and GDP growth was .71. During this period, as already discussed, poverty and inequality (VI and HI) fell significantly. Although admittedly crude, a simple way to see the relation between the oil boom and the reduction in inequality is to look at the correlation between the changes in the Gini coefficient and the changes in the oil revenues of the Non-financial public sector (NFPS). For the period analysed, this correlation is -.65 .

The recovery following the drop in oil prices in 2009 was sharp, as the shock turned out to be temporary. Following the decline, the real price of oil reached a peak in 2012, while the terms of trade peaked in 2013. In spite of the fast recovery, the initial shock already changed the macroeconomic structure of Ecuador. The trade balance, which had been positive since 2005 , became negative in 2009 , and remained negative until 2015 . The clearest effects, however, took place in the public sector. The primary surplus became negative in 2009 and shifted from a peak of $4.83 \%$ of GDP in 2006 to a low of $-5.88 \%$ in 2016. The financing needs shifted from $-2.91 \%$ in 2006 to $7.48 \%$ in 2016 . Public internal and external debt as a percentage of GDP_-which had reached a minimum in 2009 following a decision of the Ecuadorian government to stop its debt payments in December 2008-have more than doubled since then, and in 2016 were the highest of the whole period. $^{14}$

${ }^{14}$ See The Economist (2009) for a discussion on how the Ecuadorian government stopped paying its debt in 2008. 


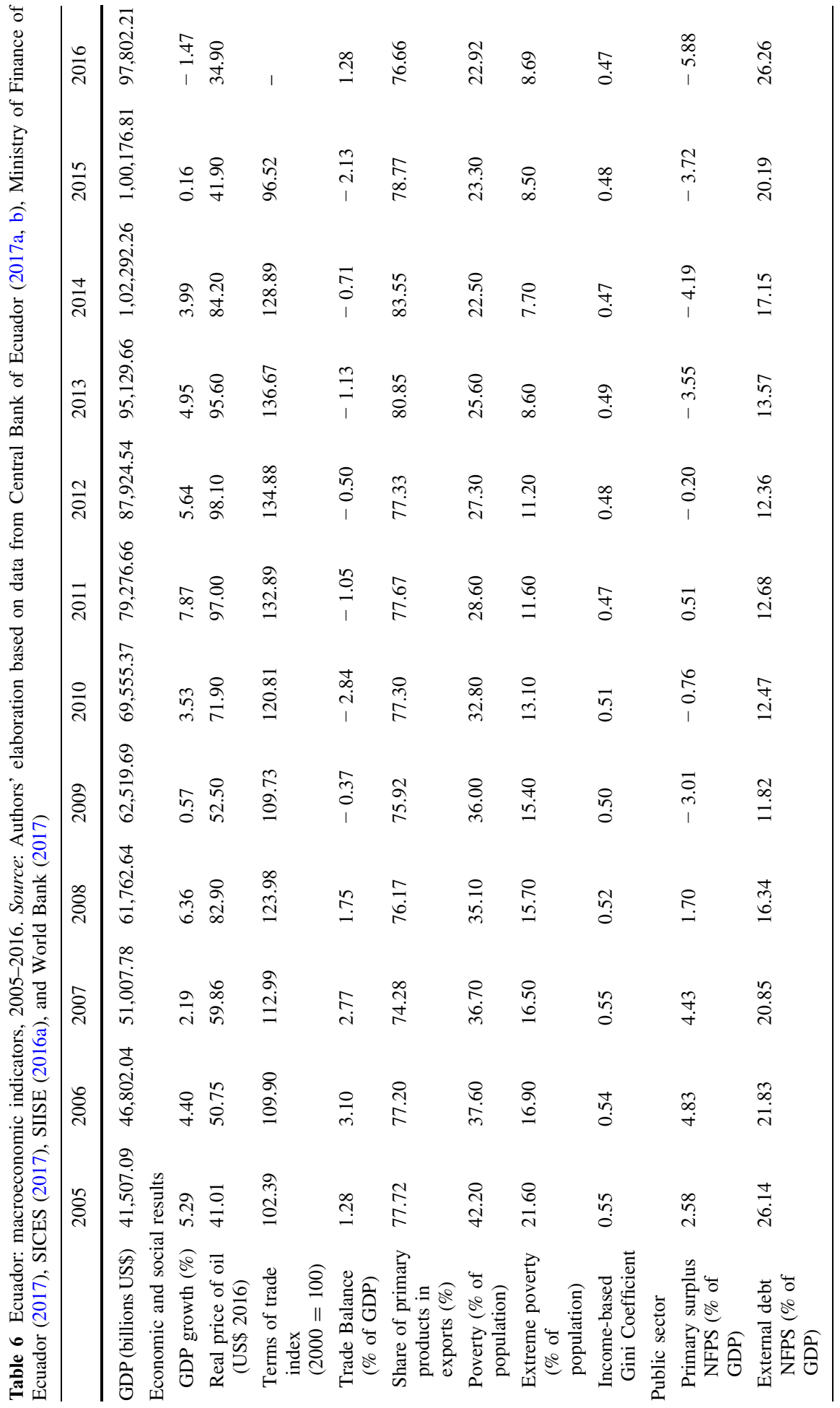




\begin{tabular}{|c|c|c|c|c|c|c|c|}
\hline 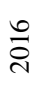 & $\stackrel{+}{\stackrel{\Delta}{I}}$ & $\stackrel{\infty}{\stackrel{\infty}{r}}$ & $\stackrel{m}{ \pm}$ & $\begin{array}{l}n \\
n \\
n\end{array}$ & 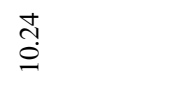 & $\stackrel{\infty}{\stackrel{\infty}{\infty}}$ & 1 \\
\hline 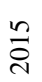 & 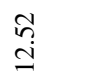 & ô. & $\begin{array}{l}\stackrel{\circ}{n} \\
\stackrel{n}{n}\end{array}$ & ले & $\stackrel{\circ}{\circ}$ & $\begin{array}{l}n \\
\infty \\
\infty\end{array}$ & $\begin{array}{l}: \\
:\end{array}$ \\
\hline$\frac{\text { त }}{\pi^{2}}$ & $\begin{array}{l}\stackrel{\infty}{\mathbb{I}} \\
\text { }\end{array}$ & $\begin{array}{l}\text { तิ } \\
\text { in }\end{array}$ & $\underset{ \pm}{ \pm}$ & $\begin{array}{l}\stackrel{0}{0} \\
\stackrel{0}{0}\end{array}$ & ஸ̆ & $\stackrel{\sigma}{\sigma}$ & $\stackrel{\hat{\imath}}{0}$ \\
\hline$\stackrel{m}{i}$ & $\stackrel{?}{\stackrel{9}{\circ}}$ & $\stackrel{n}{i}$ & 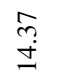 & 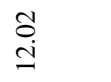 & $\ddot{n}$ & $\begin{array}{l}\text { : } \\
0\end{array}$ & $\stackrel{\infty}{\circ}$ \\
\hline 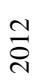 & $\begin{array}{l}\infty \\
\infty \\
\infty\end{array}$ & ț & $\stackrel{\Delta}{\stackrel{\sigma}{g}}$ & $\begin{array}{l}\dddot{n} \\
\ddot{n}\end{array}$ & $\stackrel{a}{a}$ & $\underset{\substack{n \\
\infty \\
\infty}}{ }$ & $\stackrel{\infty}{\infty}$ \\
\hline $\overrightarrow{\vec{i}}$ & $\begin{array}{l}\infty \\
\dot{\infty} \\
i\end{array}$ & $\stackrel{m}{0}$ & 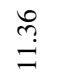 & ָ̃ & $\stackrel{0}{a}$ & $\underset{\infty}{8}$ & ó \\
\hline$\stackrel{ }{\stackrel{2}{d}}$ & $\vec{\pi}$ & 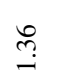 & $\stackrel{\vec{\beth}}{\Xi}$ & $\stackrel{\infty}{\stackrel{\sim}{\leftrightarrows}}$ & $\stackrel{2}{2}$ & $\stackrel{5}{r}$ & $\stackrel{\circ}{\circ}$ \\
\hline ఫે & $\stackrel{n}{*}$ & $\sqrt[n]{n}$ & $\stackrel{n}{=}$ & $\underset{\infty}{m}$ & $\stackrel{\infty}{\stackrel{\infty}{+}}$ & $\stackrel{\infty}{\stackrel{\infty}{r}}$ & $\begin{array}{l}\circ \\
\infty \\
0\end{array}$ \\
\hline 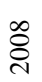 & \& & $\begin{array}{l}0 \\
n \\
i\end{array}$ & $\hat{a}$ & $\begin{array}{l}n \\
\dot{\Xi} \\
\dot{J}\end{array}$ & $\underset{\infty}{\infty}$ & ల్లి & 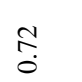 \\
\hline \&্ণ & $\ddot{n}$ & $\underset{i}{\stackrel{i}{i}}$ & $\stackrel{i}{0}$ & in & 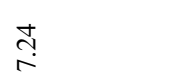 & ते & । \\
\hline ¿্خ & $\stackrel{\infty}{\infty}$ & $\overrightarrow{\widehat{i}}$ & $\stackrel{?}{\stackrel{\leftrightarrow}{0}}$ & $\bar{\sigma}$ & $\stackrel{2}{6}$ & $\underset{\sim}{\tilde{\leftarrow}}$ & 1 \\
\hline ڤ్రి & $\bar{a}$ & $\begin{array}{l}\text { to } \\
\stackrel{0}{0}\end{array}$ & $\stackrel{5}{0}$ & $\stackrel{m}{n}$ & $\underset{\sim}{\stackrel{8}{r}}$ & $\underset{f}{F}$ & \\
\hline & 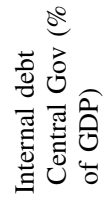 & 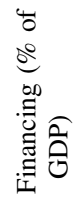 & 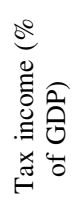 & 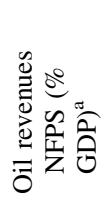 & 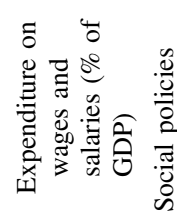 & 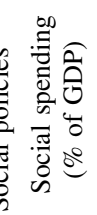 & 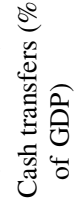 \\
\hline
\end{tabular}


These macroeconomic changes have important consequences for the mechanisms that helped reduce inequality in Ecuador, as we explain in detail below. The Social policies panel in Table 6 provides a first look at them. Public social spending as a percentage of GDP increased monotonically between 2005 and 2013. After that, however, it started to decline falling around one percentage point. Spending on the cash transfers program also increased starting in 2008. It reached a peak of $1.08 \%$ in 2013 , declining significantly afterwards. ${ }^{15}$ Indeed, in 2015 , the cash transfer program represented a smaller fraction of GDP than it did in 2008. Of course, a large part of this reduction follows from the "graduation" process that started in 2013, according to which beneficiary households not living in extreme poverty had to exit the program. However, looking at the years 2014 and 2015, the decline in expenditure on the program (as a percentage of GDP) is not consistent with the rise in extreme poverty. Indeed, between 2014 and 2016 poverty and extreme poverty increased. Inequality has stagnated after 2011.

Considering this context, in what follows we analyse the causes of the recent inequality reduction in Ecuador. There are several possible mechanisms, which we discuss in turn.

Following Gasparini et al. (2016), the first reason for the reduction in inequality is the recovery following a crisis. As these authors mention, the crises at the end of the 1990s in Latin America led to increases in inequality, which were reverted during the recovery that followed. But, once the recovery took hold, the equalizing effect ended. At first glance, this might seem consistent with the Ecuadorian experience and the crisis of 1999, as indeed we do have evidence of an increase in VI and HI during the crisis (see Table 3) and a decline thereafter (see Fig. 1). However, if this is the case, the dynamic ended during the first half of the 2000s. According to EHII (2016), the income-based Gini coefficient in 2005 was only slightly lower than in 1999 (see Fig. 1). Likewise, following the Ecuadorian LSMSs, the consumption-based Gini coefficient was almost identical in 1999 and in 2006 (see Table 3). The strongest reduction in VI and HI occurred between 2007 and 2014 (see Fig. 1 and Table 5), and thus the argument explains only a small part of the Ecuadorian experience.

An additional argument is that the reduction in inequality comes from changes in the labour market. First, the expansion of education that took place during the 1990s should reduce the earnings gap between skilled and unskilled workers in the 2000s due to the increased supply of the former (Lustig and Lopez-Calva 2010; Lustig et al. 2013; Ponce and Vos 2014). Second, the government may use public employment as a means of redistributing income when other tax-based redistribution mechanisms are more difficult to implement (Alesina et al. 2000). Third, associated with the commodities boom and the availability of resources, employment and minimum salaries may rise.

Tables 7 and 8 provide evidence on these mechanisms. Table 7 portrays the dynamic of the minimum nominal wage along with other labour market variables at the aggregate level and by groups. ${ }^{16}$ There has been a strong rise in the minimum wage, far above the increment in the CPI. ${ }^{17}$ Between 2007 and 2016, the minimum wage increased by $115 \%$ while the CPI rose by $43 \%$, implying an increment in the real minimum salary of $50 \%$. The improvement in the minimum wage, however, has occurred in parallel with a more

\footnotetext{
15 There are no official data on spending on the cash transfers program before 2008 .

16 The labour market variables are calculated since 2007. We do not include 2005 and 2006 because due to a change in methodology those years are not comparable.

17 The values for the minimum wage incorporate the two additional salaries that workers in Ecuador are entitled to.
} 


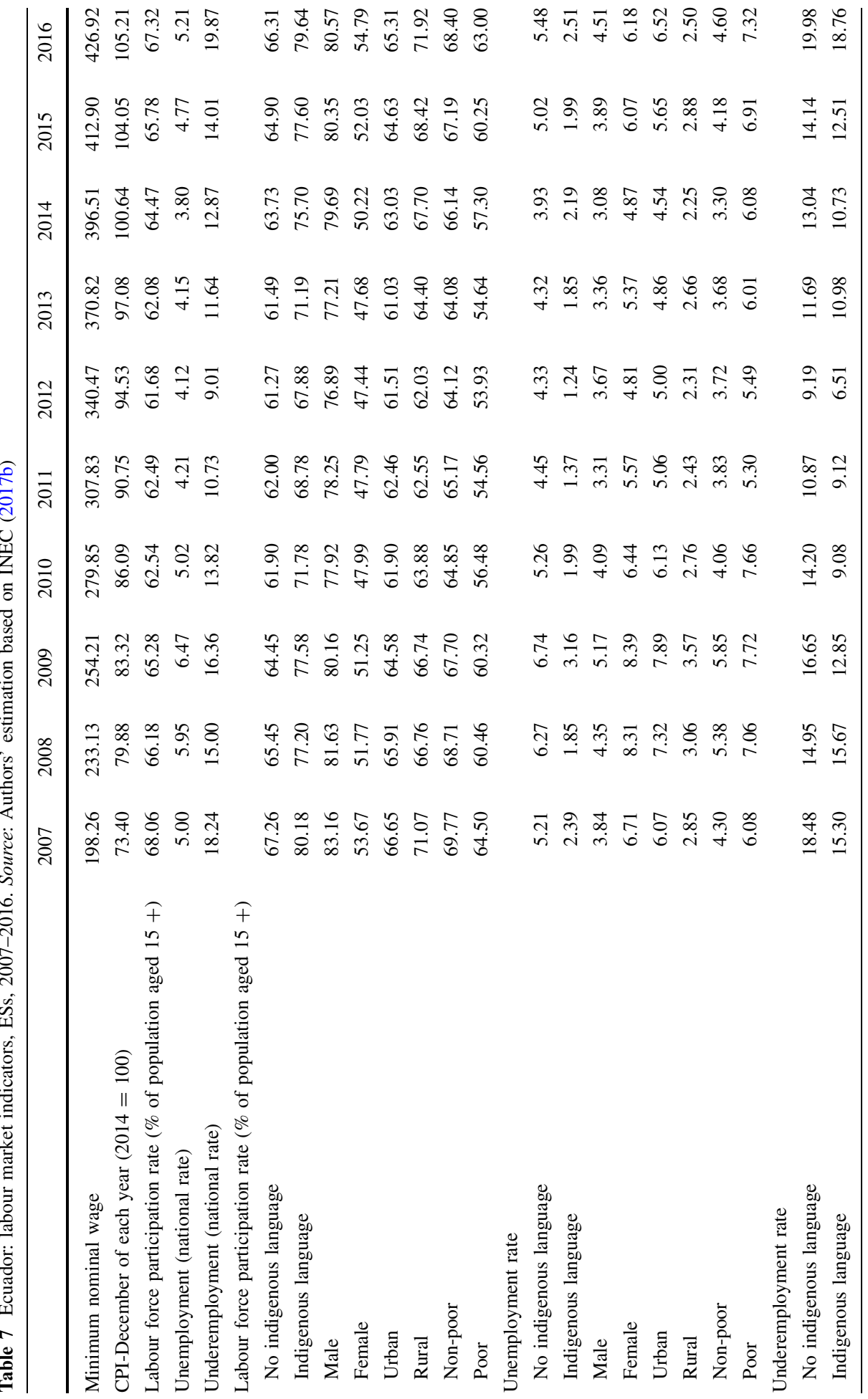




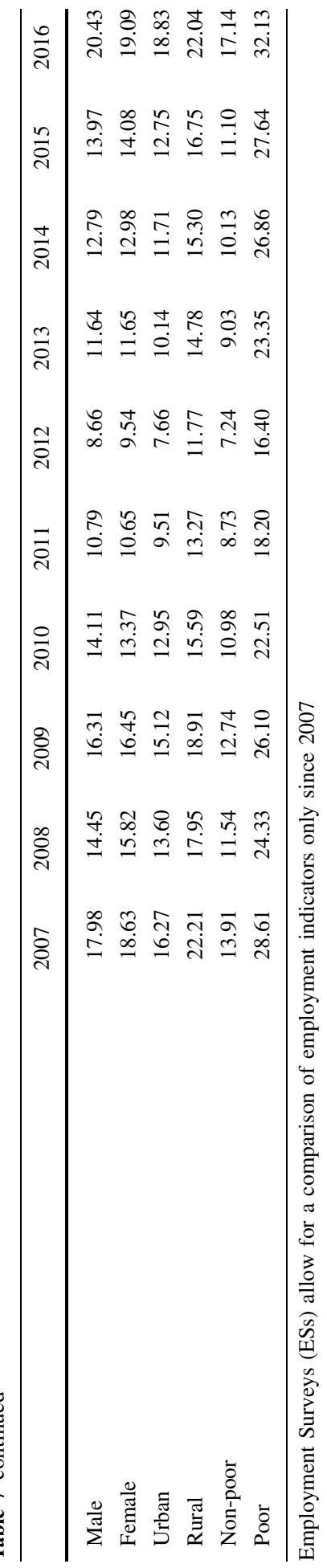




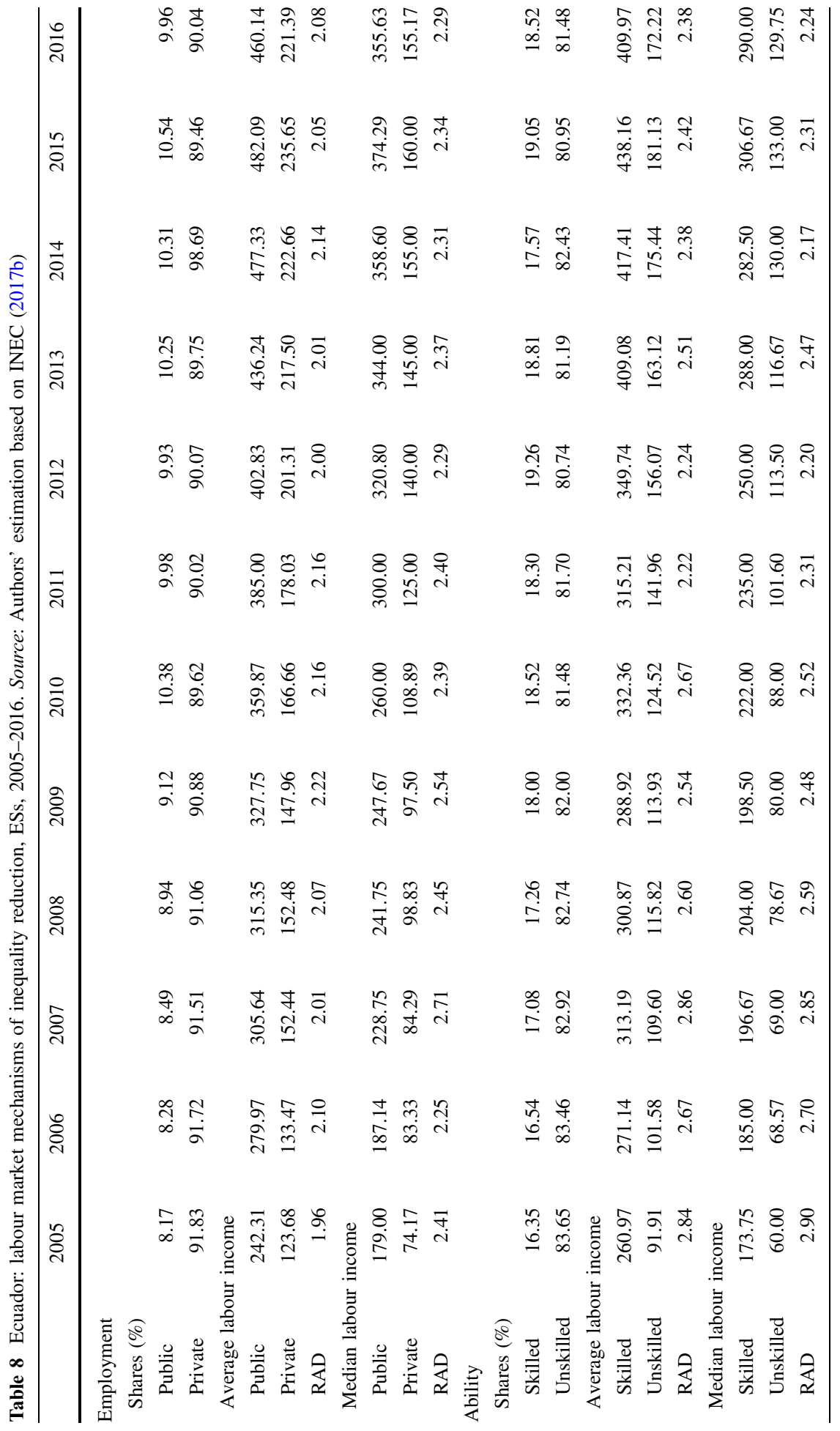


complex dynamic of the aggregate labour market variables: labour force participation, unemployment and underemployment (see Table 7). ${ }^{18}$ The evolution of these variables is $\mathrm{u}$-shaped, i.e. they fell at the beginning of the period in line with the fall in inequality; but then, at some point between 2012 and 2014, they started to rise again. By 2016, unemployment and underemployment were higher than in 2007. The largest effect occurs with underemployment. From an initial level of $18.24 \%$ in 2007, it reached a minimum of $9.01 \%$ in 2012 , only to then rise to $19.87 \%$ in 2016 . This is probably the clearest example of the cycle that Ecuador has gone through in the last decade.

To further understand the evolution of the labour market over the period, the lower panels of Table 7 present the same labour market variables but disaggregated for each one of the groups analysed throughout the paper. This shows a mechanism that allow to explain the absence of a reversion of inequality so far: a different response by advantaged and disadvantaged groups. All groups reduced their participation in the labour force up to 2012-2013, increasing it thereafter. The interesting aspect is that in every case the disadvantaged group increased its labour participation much more than the advantaged one. For instance, while people who do not speak an indigenous language raised their participation by five percentage points, people who do speak an indigenous language raised it by almost 12 percentage points. The larger flexibility among disadvantaged groups can help them cope better with an economic slowdown, at least initially, by sending to work more household members and thus compensating for the reduced income. Yet, looking at the underemployment panel, we see the limitations of this strategy. Although underemployment rose among all groups since 2012, the largest increments occurred among people who speak an indigenous language (over 12 percentage points) and the poor (almost 16 percentage points). Moreover, in 2016 the levels of underemployment are higher than they were in 2007 for all groups except people living in rural areas. As a consequence, disadvantaged groups will find it increasingly difficult to continue raising their participation, and the benefits from underemployment are likely to become smaller as the labour market turns more competitive.

Unemployment shows a complementary dynamic. There has been a rapid deterioration among advantaged groups since 2014, particularly in the cases of language and area. In the latter case, while unemployment among rural households remained essentially unchanged since 2010, among urban households it increased by around two percentage points between 2014 and 2016.

Table 7 thus shows how the disadvantaged groups' response to cope with the economic slowdown has been more aggressive in terms of increased participation. This has helped them compensate for lost income and, as a consequence, we still do not observe large increases in poverty and/or inequality.

Table 8 provides a comparison of public versus private employment. Between 2005 and 2015 the share of public employment increased by 2.37 percentage points, which might seem small but represents an increment of 29\%. In 2016 this share fell. Labour income also increased consistently between 2005 and 2016, falling in both sectors only in 2016 and in the private sector in 2009. Although labour income in the public sector was significantly larger throughout the period, the RADs - either in terms of average or median income-do not show a clear trend. The final panel presents a comparison between skilled and unskilled

\footnotetext{
18 The labour force participation rate is the ratio of the labour force to the working-age population (which in Ecuador applies to people aged 15 and over). The unemployment rate is the ratio of unemployed people to the labour force. The underemployment rate is the ratio of underemployed people (income and wage related) to the labour force.
} 
workers. During the period the share of the skilled workers increased by 2.17 percentage points, which is consistent with the idea that increments in education should lead to a larger share of skilled workers. Consistent with Lustig and Lopez-Calva (2010), Lustig et al. (2013), and Ponce and Vos (2014), the ratio of skilled to unskilled average and median incomes has fallen over the period, although with significant fluctuations.

Tables 7 and 8 thus show that the mechanisms mentioned above have actually taken place in Ecuador during recent years. Faced with a reduction in resources and an economic slowdown, these mechanisms for inequality reduction are not likely to continue in the future (Lustig et al. 2013; Ponce and Vos 2014).

A final mechanism for reducing inequality is to increase government transfers to the poor (Lustig and Lopez-Calva 2010; Lustig et al. 2013; Ponce and Vos 2014), as well as social security and retirement pensions. In Ecuador, a cash transfer program began in 1998, and it was continuously expanded until $2013 .{ }^{19}$ Until 2005, the grant was around USD 15 per month. ${ }^{20}$ Starting in 2007, the government raised its value three different times: to USD 30 in 2007, USD 35 in 2009, and USD 50 in 2013. In line with these increments, the number of beneficiaries also increased dramatically over time. According to estimations based on the LSMS-2014, in 1998, there were close to 190,000 beneficiaries, but in 2013, the number reached over 1.57 million. Relative to other programs in Latin America, Ecuador's cash transfer program was particularly large in terms of population coverage (44\% in 2010 according to Cecchini and Mandariaga 2011) and its share of GDP (see Table 6). Since its peak in 2013, many beneficiaries graduated from the program because, due to their improved economic conditions, they did not satisfy the participation requirements anymore.

To see the effects of the cash transfer program, in Table 9 we show the results of a decomposition of income inequality by source for the period 2005-2016, based on the methodology proposed by Lerman and Yitzhaki (1985). ${ }^{21}$ These authors show that the Gini coefficient of total income, $G$, can be written as:

$$
G=\sum_{k=1}^{K} S_{k} G_{k} R_{k},
$$

where $G$ is the Gini coefficient, $S_{k}$ is the share of component $k$ in total income, $G_{k}$ is the Gini coefficient of income source $k$, and $R_{k}$ is the correlation between income source $k$ and total income. $R_{k}$ measures the strength and direction of the linear relationship between income source $k$ and total income. Lerman and Yitzhaki (1985) derive the marginal effect of a percentage change in income source $k\left(e_{k}\right)$ on inequality relative to the overall Gini:

$$
\frac{\partial G / \partial e_{k}}{G}=\frac{S_{k} G_{k} R_{k}}{G}-S_{k}
$$

Clearly, this effect can be positive or negative (or zero) depending on the relationship between the parameters. In particular:

\footnotetext{
19 The program is currently called "human development bond" (BDH for its Spanish acronym).

${ }^{20}$ During the first years of the program the grant was targeted to school-aged children and newborns, seniors, and disabled individuals. President Correa's government unified the grant for all beneficiaries in 2007.

21 We use the stata code developed by Lopez-Feldman (2006).
} 


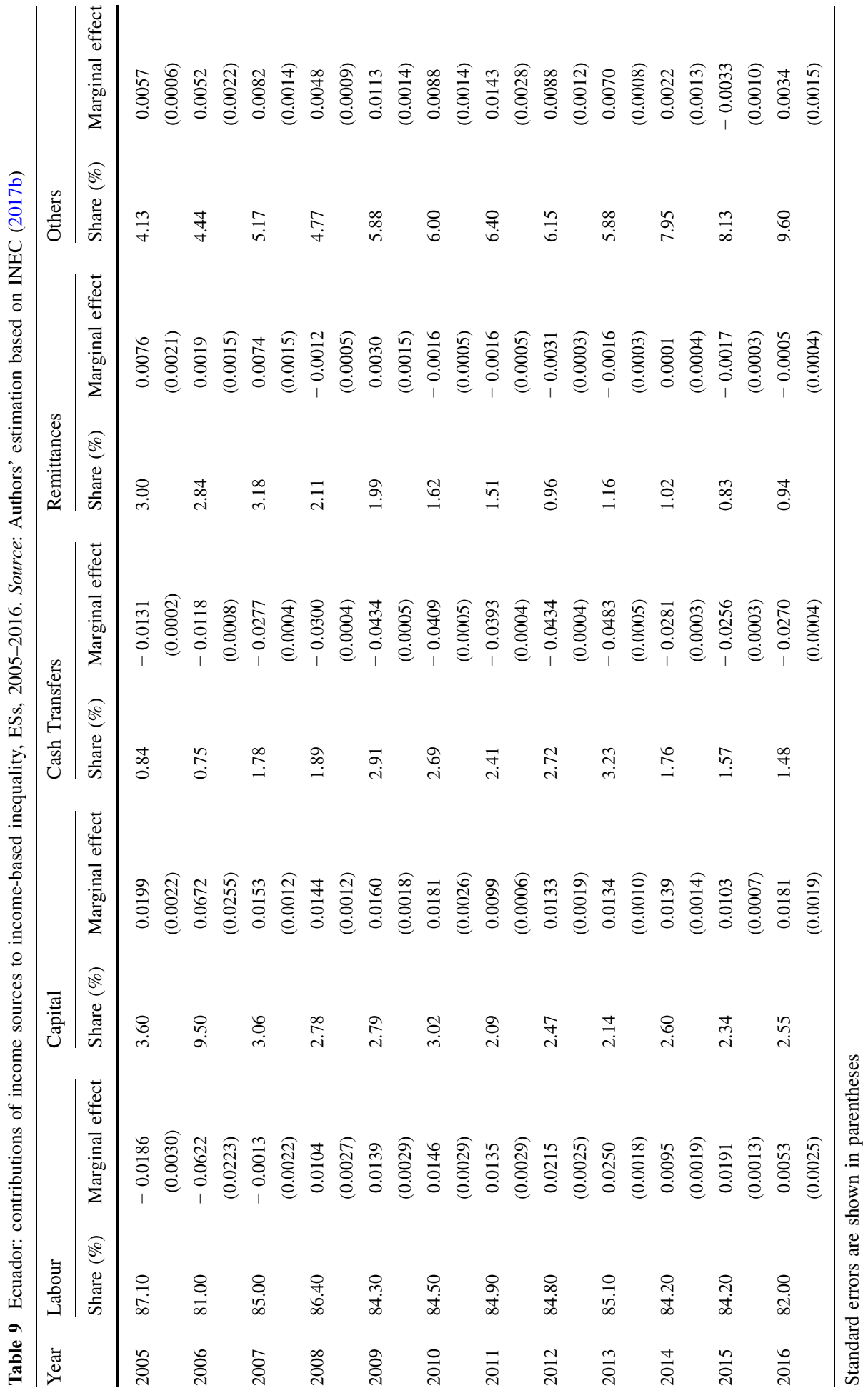




$$
\frac{\partial G / \partial e_{k}}{G} \gtrless 0 \quad \text { if } G_{k} R_{k} \gtrless G,
$$

i.e. the marginal effect is positive when income source $k$ is relatively unequal with respect to total income and the correlation between source $k$ and total income is relatively high.

We separate sources of income into labour, capital, cash transfers, remittances, and other sources of income. ${ }^{22}$ Furthermore, we provide estimations of each component's marginal effect on inequality.

The first aspect to note is that the shares of the different sources of income have changed during the period. On the one hand, since 2005 the share of labour income fell by almost five percentage points, representing only $82 \%$ in 2016. The share of capital income also fell, although not as much. And, consistent with the economic recession in the developed countries, the share of remittances declined since 2008. On the other hand, cash transfers have become more important over time, representing more than $3 \%$ of income at the peak in 2013. These changes are in line with the increments in the value of the grant in 2007, 2009, and 2013. Consistent with the decline in the number of beneficiaries, the share of cash transfers has fallen since 2013. Finally, the share of other sources of income has increased by more than five percentage points over the period, highlighting the expansion of social security benefits and retirement pensions.

In general, cash transfers have an equalizing effect, while labour, capital and other sources of income contribute to increase inequality. The effect of remittances is unclear, as it shifts signs over the years. However, it seems that their effect has become more equalizing during the second half of the period.

The marginal effect of labour income lies between .01 and .02 for most of the period and is significant in most years. This range implies that a $1 \%$ increase in labour income is associated with a 1-2\% increase in the Gini coefficient. The effect of capital income is similar in magnitude, although with more precise coefficients. Cash transfers have a stronger negative effect. A $1 \%$ increase in cash transfers leads to a reduction in the Gini coefficient of 1.2-4.8\%. Remittances have a much smaller effect. In the second half of the period an increase of $1 \%$ is associated with a fall in the Gini coefficient of .1-.3\%. The fact that remittances have an equalizing effect—although small-may seem counterintuitive. In Ecuador, the majority of households with international migrants are in the upper quantiles of the income distribution, and the amounts that they receive are also larger. Indeed, the Gini coefficient of remittances is significantly larger than the Gini coefficient of total income. However, the correlation between remittances and total income is small. In terms of (Eq. 3), although $G_{k}>G, R_{k}$ is small, and thus the marginal effect ends up being negative. It is important to note that this result is consistent with the findings of Acosta et al. (2008). Finally, other sources of income contribute to increase inequality, with a $1 \%$ increment leading to a .2-1.4\% increase in the Gini coefficient.

Two main conclusions follow from the income decomposition. First, part of the reduction in inequality comes from the shift in shares from labour income to other sources of income and cash transfers. To understand the mechanism, consider labour and other sources of income. While income from other sources tends to increase inequality, the magnitude of the effect is much smaller than the effect of labour income. As a consequence, a shift in the shares away from labour income translates into a lower level of

22 Other sources of income include social security benefits, retirement pensions, as well as donations and gifts. The first two components constitute the majority of this category. 
inequality. Cash transfers have a strong equalizing effect, and thus an increase in their share leads to lower inequality.

Second, because cash transfers and other sources of income come mainly from government resources, there seem to be two possible outcomes given the current fall in oil revenues. Either people will become more dependent on these resources or they will face a decline in their income as the government is no longer able to provide them. The limited evidence seems to show both effects. On the one hand, other sources of income represent an ever increasing share of income. On the other hand, the reduction in the number of beneficiaries of the cash transfers program since 2013 has lowered its share in income as well as its marginal effect.

These results are important because they show that a significant part of the reduction in income inequality came through expanded government benefits. The economic slowdown following the fall in oil prices has led the government to reduce its cash transfers program, and also its contributions to social security and pensions programs. As the economic downturn deepens, however, there will be more pressure on these benefits and a reform will become inevitable.

To provide additional evidence on the lack of sustainability of inequality reduction in Ecuador, we conclude this section with an analysis of the evolution of poverty over the period 2005-2016. The reduction in inequality should help reduce poverty (Bourguignon 2004) and, as shown in Table 6, the reduction in inequality in Ecuador has indeed gone hand in hand with a reduction in poverty and extreme poverty.

We use the poverty decomposition proposed by Son (2003), who decomposes the change in poverty in three components and explicitly considers between-group variations. The components are: within group growth effect, within group inequality effect, and population shift among groups, i.e. changes in the share of each of the groups. ${ }^{23}$

Table 10 shows the results for each of the dimensions that we have analysed throughout the paper: language, gender, and area. ${ }^{24}$ As can be seen, poverty declined in most years, except in 2009, 2015 and 2016. Growth during this period tended to be pro-poor in the sense that it contributed to reducing poverty. The contraction of 2016 contributed to a rise in poverty with respect to 2014. The effect of inequality is perfectly in line with intuition. In years in which inequality increased, it contributed to a rise in poverty, and in years in which it declined, it contributed to reducing poverty.

The general perspective provided by Table 10 is that economic slowdowns tend to increase poverty. This is clearly shown for the contraction in 2016. More importantly, the drop in oil prices since 2014 has changed the dynamics of poverty, which has been higher in the last two years than in 2014. In 2015 this was mainly due to the effect of a rise in inequality and in 2016 it was mainly due to the economic contraction.

The dynamics of poverty shown above and especially the recent rise thereof, provide further evidence of the unsustainable path of inequality reduction. After an economic boom, increases in poverty are associated with increases in inequality. Thus, as poverty rises, we expect inequality to rise as well.

\footnotetext{
${ }^{23}$ Son (2003) proposes a further decomposition of the growth effect, but it is not necessary for our purposes.

${ }^{24}$ Of course, the poverty dimension cannot be analysed in this context because we are precisely looking at the effects of each component on the poverty share.
} 


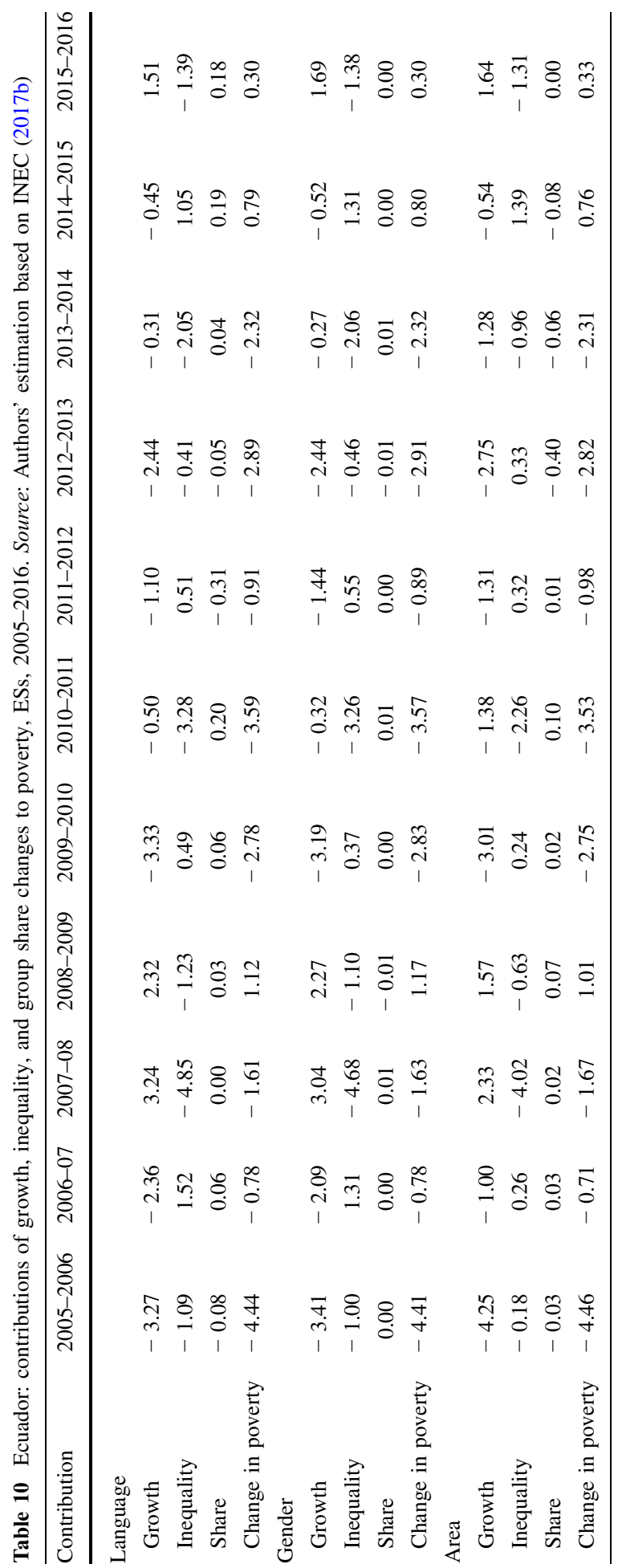




\section{Discussion}

The previous section provided evidence that Ecuador's large inequality reduction during the last decade is not sustainable. Here, we present a discussion and a possible explanation for this result, consistent with much of the literature on the resource curse, and the historical Latin American experience.

As discussed by Gasparini et al. (2016), the Ecuadorian experience of inequality reduction is not isolated. The decline in inequality was a regional phenomenon, as is the recent stagnation, although with some heterogeneity. Consistent with previous studies, the reduction in growth will most likely lead to an increase in inequality and poverty (Psacharopoulos et al. 1995; Ravallion and Chen 1997; Lustig and Lopez-Calva 2010). On the one hand, the closing gap between skilled and non-skilled workers' salaries followed at least in part from the strong demand for commodities, whose production is intensive in low-skilled workers. The fall in the prices of commodities means a lower demand for this type of workers, which in turn implies a decline in their relative wages. On the other hand, slow economic growth means lower taxes, which limit social spending (including education) and also transfer, social security, and pension programs. Indeed, Aldunate and Martner (2006) argue that social spending in Latin America has a large pro-cyclical bias.

The dynamic of inequality is, to a large extent, a reflection of the lack of sustainability of the policies followed during the last decade. Despite the optimism of some authors regarding a change in macroeconomic policies (see e.g. Sáenz 2014), the fall in the price of commodities has uncovered the structural weaknesses of some Latin American economies, and Ecuador in particular. The lack of sustainable social policies along with the suboptimal administration of fiscal resources means that part of the progress made may be lost in the next years. In this context, authors such as Lustig et al. (2013) and Ponce and Vos (2014) emphasize the need for a change in the economic structure so that it becomes less dependent on commodities-particularly oil-, an improvement in the quality of education, and a broad-based tax reform. The recent experience shows that these mechanisms are hard to implement.

But the real challenge lies elsewhere. As argued by Acemoglu et al. (2003), macroeconomic imbalances-and their consequences-are symptoms of a deeper cause: institutional weaknesses, and particularly weak political institutions that distribute power unequally. In the context of inequality reduction, it seems that the lack of sustainability comes from the pro-cyclical policies followed by the governments in charge of administering the revenues from the commodities boom. Reducing inequality in social and economic dimensions requires sustained redistributive policies, which in turn require strong democratic institutions (Robinson 2006; Lustig and Lopez-Calva 2010).

Reducing inequality thus requires political equality, understood as equality in the distribution of political power, political rights, influence, and access to the political system (Robinson 2006). The reason is that political institutions affect economic institutions and, most importantly, the political distribution of power affects the distribution of economic power in a virtuous or vicious circle (Acemoglu et al. 2005). What needs to change then is not the elite in power but the incentives of the elite that comes to power.

Failure to understand this fundamental point risks falling into the iron law of oligarchy, which Acemoglu and Robinson (2006) describe as follows:

The iron law of oligarchy emerges when the current elite are replaced by newcomers, sometimes with a popular mandate, and yet once these newcomers are in power they have no incentive to change the oligarchic structure, and instead use the 
entrenchment provided by the existing political institutions for their own benefit (Acemoglu and Robinson 2006, p. 329).

When this occurs, weak political and economic institutions tend to persist and, as a consequence, social and economic outcomes such as inequality and poverty are difficult to change. Indeed, this perspective explains the pattern of persistent inequality in Ecuador shown above. While the country was able to reduce inequality in the past, the reversal that followed occurred precisely because of a lack of strong institutions.

Throughout its history, Ecuador has been characterized by institutional weaknesses as exemplified most recently by having had eight presidents in the period 1997-2007. Looking back over a longer time frame, Ecuador is notorious for its lack of institutional stability. During its republican period Ecuador has had 20 constitutions, each one lasting on average 9 years, and its laws are routinely disrespected. Furthermore, as discussed in Andrango et al. (2016), Ecuador is characterized by continuous political conflict and a disdain for institutions by strong political leaders.

After the 1997-2007 period of political and economic volatility-and thanks in large part to the high price of oil-since 2007 Ecuador has enjoyed a period of political stability and strong economic growth, accompanied by important social achievements. However, the country has become less democratic. Andrango et al. (2016) provide evidence on the reduction of executive constraints and the lack of freedom of the press. Table 11 shows disaggregated scores from Freedom House (2017) for the period 2005-2016. Higher scores imply more political rights and civil liberties.

As can be seen, there is a clear trend towards lower scores. In Ecuador, the electoral process is dominated by the executive, and political pluralism and participation, as well as freedom of expression and organization rights have been severely limited. As a consequence, power has been centralized in the state and civil society has lost its voice and representation. A new governing elite has replaced the old one but, in the process, it has adopted similar behaviours, precisely along the logic of the iron law of oligarchy. The incentives of the elite have not changed, and the current elite has not made progress in changing the incentives for the future governments. Indeed, as argued by Conaghan (2016):

Using the 2008 Constitution as a starting point and with help from the judicial branch, Correa has overseen an exhaustive legal restructuring. Whether in his hands or those of a successor, the illiberal features now thereby entrenched will allow for nondemocratic governance to continue (Conaghan 2016, p. 117).

The abundance of resources due to the oil boom along with a new Constitution and extremely high popularity constituted a once in a generation opportunity to change these incentives. For example, Gachet et al. (2017) document the impressive fact that the middle class in Ecuador doubled between 2005 and 2015. Despite this and other significant improvements presented in this article, the lack of a democratic perspective prevented the country from taking advantage of this favourable time.

\section{Conclusions}

After a rise in inequality during the 1990s, Ecuador has experienced an important reduction in vertical and horizontal inequality during the last 15 years, and particularly during the last decade. This reduction in inequality coincided with an oil boom-two elements that do not necessarily go together. As argued by Ross (2007), and Ross et al. (2012), faced with a 


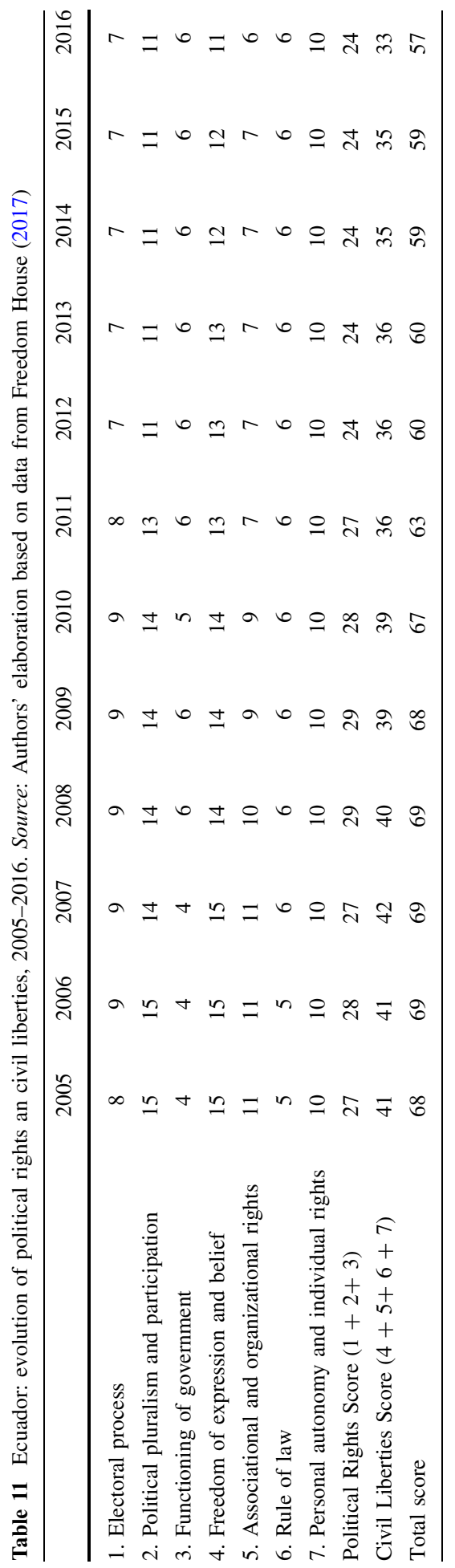


natural resource boom, politicians have an incentive to direct the revenues towards their own benefit. The reduction in inequality is an encouraging sign that politicians have at least in part resisted the temptation of concentrating the windfalls from oil. Maybe, at least in the short-run, the still fresh experience of the 1999 crisis and the significant political instability of the 1997-2006 period imposed an implicit check on politicians, who became more conscious of the need to respond to the electorate.

The progress made regarding poverty and inequality during the last 15 years is undeniable, as all the evidence presented here confirms. Moreover, education, consumption, and income gaps between advantaged and disadvantaged groups have all improved during this period. It is also undeniable, however, that there are early signs of a reversal, with poverty and inequality stagnating or rising.

As we mentioned in the introduction, at least two questions become relevant in this context. First, what were the causes of the reduction in inequality? The simultaneity between the rise to power of a leftist government and the peak of the oil boom makes it difficult to provide a definitive answer. Yet, there is evidence that government policies including expansion of the cash transfer program, public employment, higher minimum salaries, and social security benefits and pensions have contributed to the reduction in inequality. These policies, however, are all dependent on the availability of resources associated with the oil boom. Hence, while policies did matter, it seems highly unlikely that they could have been implemented in the absence of the windfalls from the commodities boom.

Second, there is the question to which we have attempted to provide an answer: are the results sustainable? The fall in the price of oil since October 2014 has led to a clear deterioration of Ecuador's macroeconomic indicators, especially the fiscal ones. As a consequence, the well-being of Ecuador's households, and particularly of the more vulnerable groups, is declining. The full effect of the economic slowdown, however, has been limited so far in large part thanks to the rise in internal and external public debt. But this cannot be sustained indefinitely and a broad reform will need to be implemented in the near future. Thus, the available evidence along with the economic prospects support the argument that the reduction in inequality was indeed unsustainable. It seems that the pattern of inequality presented in Fig. 1 for the 1970s and the 1980s is likely to repeat itself.

In the end, it clearly makes more sense to have slow but sustainable progress than spectacular results that are reversed soon after (Collier 2007). This sort of progress requires a strong democratic sense to promote political equality and to alter the elites' incentives.

Acknowledgements We thank the United Nations University World Institute for Development Economics Research (UNU-WIDER) for financial support. We also thank Carla Canelas, Rachel Gisselquist, Johanna Andrango, participants at the Group-based Inequalities: Patterns, Trends Within and Across Countries Project Workshop in Helsinki, and two anonymous referees for helpful comments and suggestions. All remaining errors are ours. The views expressed herein are those of the authors and do not necessarily reflect those of UNU-WIDER.

Open Access This book is licensed under the terms of the Creative Commons Attribution-NonCommercialShareAlike 3.0 IGO License (https://creativecommons.org/licenses/by-nc-sa/3.0/igo/), which permits any noncommercial use, sharing, adaptation, distribution, and reproduction in any medium or format, as long as you give appropriate credit to the UNU-WIDER, provide a link to the Creative Commons licence and indicate if changes were made. If you remix, transform, or build upon this book or a part thereof, you must distribute your contributions under the same licence as the original. 


\section{References}

Acemoglu, D., Johnson, S., \& Robinson, J. A. (2005). Institutions as a fundamental cause of long-run growth. In P. Aghion \& S. Durlauf (Eds.), Handbook of economic growth (Vol. 1A, pp. 386-472). Amsterdam: Elsevier.

Acemoglu, D., Johnson, S., Robinson, J. A., \& Thaicharoen, Y. (2003). Institutional causes, macroeconomic symptoms: Volatility, crises and growth. Journal of Monetary Economics, 50, 49-123.

Acemoglu, D., \& Robinson, J. A. (2006). De facto political power and institutional persistence. The American Economic Review, 96(2), 325-330.

Acosta, P., Calderón, C., Fajnzylber, P., \& Lopez, H. (2008). What is the impact of international remittances on poverty and inequality in Latin America? World Development, 36(1), 89-114.

Aldunate, E., \& Martner, R. (2006). Fiscal policy and social protection. CEPAL Review, 90, 87-104.

Alesina, A., Baqir, R., \& Easterly, W. (2000). Redistributive public employment. Journal of Urban Economics, 48(2), 219-241.

Alesina, A., Devleeschauwer, A., Easterly, W., Kurlat, S., \& Wacziarg, R. (2003). Fractionalization. Journal of Economic Growth, 8(2), 155-194.

Andrango, J. E., Grijalva, D. F. \& Romero, P. P. (2016). Liberalism in Ecuador: In search of a constitution. USFQ Department of Economics Working Paper. Quito: USFQ.

Barro, R. J., \& Lee, J. W. (2015). Education matters. New York: Oxford University Press.

Birdsall, N., Lustig, N., and McLeod, D. (2011). Declining inequality in Latin America: Some economics, some politics. Working Paper 251. Washington, D. C.: Center for Global Development.

Bourguignon, F. (2004). The poverty-growth-inequality triangle. World Bank Working Paper.

Buccellato, T., \& Mickiewicz, T. (2009). Oil and gas: A blessing for the few. hydrocarbons and inequality within regions in Russia. Europe-Asia Studies, 61(3), 385-407.

Caumartin, C., Gray-Molina, G., \& Thorp, R. (2008). Inequality, ethnicity and political violence in Latin America: The cases of Bolivia, Guatemala and Peru. In F. Stewart (Ed.), Horizontal inequalities and conflict: Understanding group violence in multiethnic societies (pp. 227-251). New York: Palgrave Macmillian.

Cecchini, S., \& Madariaga, A. (2011). Programas de transferencias condicionadas: Balance de la experiencia reciente en América Latina y el Caribe. Santiago: CEPAL.

Central Bank of Ecuador. (2012). Series Estadísticas Históricas 1927-2012. http://biblioteca.bce.ec/cgi-bin/ koha/opac-detail.pl?biblionumber=44001. Accessed 20 Feb 2017.

Central Bank of Ecuador. (2017a). Boletín anuario. https://www.bce.fin.ec/index.php/component/k2/item/ 776. Accessed 30 Sept 2017.

Central Bank of Ecuador. (2017b). Información Estadística Mensual. https://www.bce.fin.ec/index.php/ component/k2/item/776. Accessed 20 Feb 2017.

Collier, P. (2007). The bottom billion. New York: Oxford University Press.

Conaghan, C. (2016). Delegative democracy revisited: Ecuador under correa. Journal of Democracy, 27(3), 109-118.

Cornia, G. A. (2014). Inequality trends and their determinants: Latin America over the period 1990-2010. In G. A. Cornia (Ed.), Falling inequality in Latin America. Policy changes and lessons. New York: Oxford University Press.

Deininger, K., \& Squire, L. (1996). A new data set measuring income inequality. The World Bank Economic Review, 10, 565-591.

Donoso, J. C., Montalvo, D., Orcés, D., \& Zechmeister, E. J. (2015). Cultura política de la democracia en Ecuador y en las Américas, 2014: Gobernabilidad democrática a través de 10 años del Barómetro de las Americas. Nashville, TN: Vanderbilt University.

ECLAC. (2015). Panorama Social de América Latina 2015. https://www.cepal.org/es/publicaciones/39965panorama-social-america-latina-2015. Accessed 30 Jan 2017.

ECLAC. (2017). Statistics and indicators. CEPALSTAT databases and statistical publications. http:// estadisticas.cepal.org/cepalstat/WEB_CEPALSTAT/estadisticasIndicadores.asp?idioma=i. Accessed 30 Jan 2017.

Fearon, J. D. (2003). Ethnic and cultural diversity by country. Journal of Economic Growth, 8(2), $195-222$.

Feres, J. C., \& Mancero, X. (2001). El método de las necesidades básicas insatisfechas (NBI) y sus aplicaciones en América Latina. Santiago: CEPAL.

Freedom House. (2017). Freedom in the world comparative and historical data. Technical report, Washington D. C.: Freedom House.

Gachet, I., Grijalva, D., Ponce, P., \& Rodríguez, D. (2017). The rise of the middle class in Ecuador during the oil boom. Cuadernos de Economía, 36(72), 327-352. 
Gachet, I., Maldonado, D., Oliva, N., \& Ramírez, J. (2011). Hechos estilizados de la economía Ecuatoriana: El ciclo económico 1965-2008. Revista Fiscalidad, 6, 59-120.

Gasparini, L., Cruces, G. \& Tornarolli, L. (2016). Chronicle of a deceleration foretold: Income inequality in Latin America in the 2010s. CEDLAS Working Papers.

Gasparini, L. \& Lustig, N. (2011). The rise and fall of income inequality in Latin America. CEDLAS Working Papers.

Gisselquist, R. M. (2015). Project overview note. Group-based inequalities: Patterns and trends within and across countries. Helsinki: UNU WIDER.

Goderis, B., \& Malone, S. W. (2011). Natural resource booms and inequality: Theory and evidence. The Scandinavian Journal of Economics, 113(2), 388-417.

Gylfason, T., \& Zoega, G. (2003). Inequality and economic growth: Do natural resources matter? In T. Eicher \& S. Turnovsky (Eds.), Inequality and growth: Theory and policy implications. Cambridge, MA: MIT Press.

Howie, P., \& Atakhanova, Z. (2014). Resource boom and inequality: Kazakhstan as a case study. Resources Policy, 39, 71-79.

INEC. (2011). Censo de Población y Vivienda (various years). http://www.ecuadorencifras.gob.ec//bancode-informacion/. Accessed 08 Jan 2017.

INEC. (2015). Encuesta de Condiciones de Vida (various years). http://www.ecuadorencifras.gob.ec//bancode-informacion/. Accessed 08 Jan 2017.

INEC. (2017a). Históricos IPC. http://www.ecuadorencifras.gob.ec/historicos-ipc/. Accessed 26 Feb 2017.

INEC. (2017b). Encuesta Nacional de Empleo, Desempleo y Subempleo (various years). http://www. ecuadorencifras.gob.ec//banco-de-informacion/. Accessed 16 Feb 2017.

International Monetary Fund. (2017). Real GDP growth. World Economic Outlook. IMF DataMapper. http:// www.imf.org/external/datamapper/NGDP_RPCH@WEO/OEMDC/ADVEC/WEOWORLD/ECU. Accessed 30 Sept 2017.

Lerman, R. I., \& Yitzhaki, S. (1985). Income inequality effects by income source: A new approach and applications to the United States. The Review of Economics and Statistics, 67, 151-156.

Loayza, N., \& Rigolini, J. (2016). The local impact of mining on poverty and inequality: Evidence from the commodity boom in Peru. World Development, 84, 219-234.

Lopez-Feldman, A. (2006). Decomposing inequality and obtaining marginal effects. Stata Journal, 6, 106111.

Lustig, N., \& Lopez-Calva, L. F. (2010). Explaining the decline in inequality in Latin America: Technological change, educational upgrading, and democracy. In N. Lustig \& L. F. López-Calva (Eds.), Declining inequality in Latin America. A decade of progress? Chapter 1. Washington D. C: Brookings Institution Press and United Nations Development Programme.

Lustig, N., López-Calva, L. F., \& Ortiz-Juárez, E. (2013). Declining inequality in Latin America in the 2000s: The cases of Argentina, Brazil, and Mexico. World Development, 44, 129-141.

Martinez, G. (2006). The political economy of the Ecuadorian financial crisis. Cambridge Journal of Economics, 30(4), 567-585.

Ministry of Finance of Ecuador. (2017). Boletín de Ejecución Presupuestaria. http://www.finanzas.gob.ec/ biblioteca/. Accessed 30 June 2017.

Ponce, J., \& Vos, R. (2014). Redistribution without structural change in Ecuador: Rising and falling income inequality in the 1990s and 2000. In G. A. Cornia (Ed.), Falling inequality in Latin America. New York: Oxford University Press.

Psacharopoulos, G., Morley, S., Fiszbein, A., Lee, H., \& Wood, W. C. (1995). Poverty and income inequality in Latin America during the 1980s. Review of Income and Wealth, 41, 245-264.

Ravallion, M., \& Chen, S. (1997). What can new survey data tell us about recent changes in distribution and poverty? The World Bank Economic Review, 11, 357-382.

Robinson, J. A. (2006). Equity, institutions and the development process. Nordic Journal of Political Economy, 32, 17-50.

Ross, M. L. (2007). How mineral-rich states can reduce inequality. In M. Humphreys, J. D. Sachs, \& J. E. Stiglitz (Eds.), Escaping the resource curse. New York: Columbia University Press.

Ross, M. L., Lujala, P., \& Rustad, S. A. (2012). Horizontal inequality, decentralizing the distribution of natural resource revenues, and peace. In P. Lujala \& S. A. Rustad (Eds.), High-value natural resources and post-conflict peacebuilding. London: Earthscan.

Sáenz, M. (2014). The case of Ecuador. In L. Czarnecki, E. Balleza, \& M. Sáenz (Eds.), Poverty and inequality in Ecuador, Brazil and Mexico after the 2008 global crisis, Kozminski studies in management and economics. Frankfurt: Peter Lang.

SICES. (2017). Pobreza y Desigualdad. Estadística. http://www.conocimientosocial.gob.ec/pages/ EstadisticaSocial/herramientas.jsf. Accessed 25 Feb 2017. 
SIISE. (2016a). Desigualdad y Pobreza. Consultas Temáticas. http://www.siise.gob.ec/siiseweb/siiseweb. html?sistema=1. Accessed 25 Feb 2017.

SIISE. (2016b). Ficha metodológica-encuesta urbana de empleo, desempleo y subempleo (ENEMDU)— INEC. http://www.siise.gob.ec/siiseweb/PageWebs/Fuentes/ficfue_eued.htm. Accessed 10 Feb 2017.

SIISE. (2016c). Ficha metodológica—encuesta de condiciones de vida (ecv)—inec. http://www.siise.gob.ec/ siiseweb/PageWebs/Fuentes/ficfue_ecv.htm. Accessed 10 Feb 2017.

SIISE. (2016d). Ficha metodológica-censo de población y vivienda-INEC. http://www.siise.gob.ec/ siiseweb/PageWebs/Fuentes/ficfue_censos.htm. Accessed 10 Feb 2017.

SIISE. (2017). Listado de nacionalidades y pueblos indígenas del Ecuador. http://www.siise.gob.ec/ siiseweb/PageWebs/glosario/ficglo_napuin.htm. Accessed 10 Feb 2017.

Son, H. H. (2003). A new poverty decomposition. Journal of Economic Inequality, 1(2), 181-187.

Stewart, F. (2000). The root causes of humanitarian emergencies. In W. Nafziger, F. Stewart, \& R. Väyrynen (Eds.), War, hunger, and displacement. The origins of humanitarian emergencies. New York: Oxford University Press.

Stewart, F. (2008). Horizontal inequalities and conflict: An introduction and some hypotheses. In F. Stewart (Ed.), Horizontal inequalities and conflict: Understanding group violence in multiethnic societies. New York: Palgrave Macmillian.

Stewart, F. (2016). Changing perspectives on inequality and development. Studies in Comparative International Development, 51(1), 60-80.

The Economist. (2009). Ecuador's winning strategy. http://www.economist.com/node/13854456. Accessed 25 Jan 2017.

Tsounta, E. \& Osueke, A. I. (2014). What is behind Latin America's declining income inequality? IMF Working Paper.

University of Texas Inequality Project-EHII. (2016). Estimated household income inequality data set (EHII). http://utip.lbj.utexas.edu/data.html. Accessed 25 Feb 2017.

World Bank. (2017). World development indicators database. http://data.worldbank.org/data-catalog/worlddevelopment-indicators. Accessed 30 Sept 2017. 